\title{
The Physico-Chemical Quality of Streams and Channels Draining into River Rwizi, South Western Uganda
}

\author{
Jeninah Atwebembeire1 ${ }^{*}$, Joel Bazira ${ }^{2}$, Grace Kagoro', Jane Yatuha1, Morgan Andama ${ }^{3}$, \\ Julius Lejju Bunny ${ }^{1}$ \\ ${ }^{1}$ Department of Biology, Faculty of Science, Mbarara University of Science and Technology, Mbarara, Uganda \\ ${ }^{2}$ Department of Microbiology, Faculty of Medicine, Mbarara University of Science and Technology, Mbarara, Uganda \\ ${ }^{3}$ Department of Biology, Faculty of Science, Muni University, Arua, Uganda \\ Email: ^atwebembeirej@must.ac.ug
}

How to cite this paper: Atwebembeire, J., Bazira, J., Kagoro, G., Yatuha, J., Andama, M. and Bunny, J.L. (2018) The PhysicoChemical Quality of Streams and Channels Draining into River Rwizi, South Western Uganda. Journal of Water Resource and Protection, 10, 817-845.

https://doi.org/10.4236/jwarp.2018.109047

Received: July 28, 2018

Accepted: September 1, 2018

Published: September 4, 2018

Copyright $\odot 2018$ by authors and Scientific Research Publishing Inc. This work is licensed under the Creative Commons Attribution International License (CC BY 4.0).

http://creativecommons.org/licenses/by/4.0/

c) (i) Open Access

\begin{abstract}
There is an increased human population along the catchment area of river Rwizi who are engaged in various activities with potential to contaminate river Rwizi especially along the streams. Studies have been done to examine the physico-chemical quality of the mainstream river Rwizi in Mbarara Municipality. However, the comprehensive source of contamination may be beyond the municipality and yet the streams have not been investigated to substantiate their contribution on quality degradation of the river and this formed the basis of the study. This study determined the physico-chemical parameters of streams draining into river Rwizi. Raw water was purposively selected from streams in the upstream, midstream and downstream sections of the river. Water samples were analyzed for 15 physico-chemical parameters including dissolved oxygen (DO), colour, turbidity, total suspended solid (TSS), total iron ( $\mathrm{Fe})$, phosphates $\left(\mathrm{PO}_{4}^{3-}\right)$, alkalinity, magnesium $(\mathrm{Mg})$, calcium carbonate $\left(\mathrm{CaCO}_{3}\right)$, temperature, $\mathrm{pH}$, ammonium $\left(\mathrm{NH}_{4}^{+}\right)$, electrical conductivity (EC), chloride $(\mathrm{Cl})$ and nitrates $\left(\mathrm{NO}_{3}\right)$. The water samples were analyzed following the standard methods of American Public Health Association and standard operating manual (1985). The obtained values were also compared with the international Environmental Protection Agency (EPA, 2001) guidelines for water quality and the National Environment Management Authority (NEMA, 1999) standards for waste water. The results showed that most of the streams in the downstream generally recorded the highest levels $(\mathrm{p}<0.05)$ of the physico-chemical parameters followed by the midstream and lastly the upstream. Streams in the downstream recorded the highest levels in most of the parameters tested i.e. bus park stream (tempera-
\end{abstract}


ture, $27.6^{\circ} \mathrm{C}$; colour, $431.17 \mathrm{TCU}$; TSS, $99.33 \mathrm{mg} / \mathrm{l}$; alkalinity, $468.33 \mathrm{mg} / \mathrm{l}$; $\mathrm{Mg}, 121.89 \mathrm{mg} / \mathrm{l} ; \mathrm{CaCO}_{3}, 588.67 \mathrm{mg} / \mathrm{l} ; \mathrm{Cl}, 333.33 \mathrm{mg} / \mathrm{l}$ ), Kikutu stream (turbidity, $123.58 \mathrm{NTU}$; EC, $698 \mu \mathrm{s} / \mathrm{cm}$; DO, $\left.55.73 \mathrm{mg} / \mathrm{l} ; \mathrm{PO}_{4}^{3-}, 12.85 \mathrm{mg} / \mathrm{l}\right), \mathrm{Ka}-$ kyeka upper ( $\left.\mathrm{pH}, 10.52 ; \mathrm{NH}_{4}^{+}, 46.67 \mathrm{mg} / \mathrm{l}\right)$, Rwentondo $(\mathrm{Fe}, 3.44 \mathrm{mg} / \mathrm{l})$ and Kakyeka GBK $\left(\mathrm{NO}_{3}, 10.83 \mathrm{mg} / \mathrm{l}\right)$. Most of the parameters downstream were higher than the EPA guideline (temperature, $25^{\circ} \mathrm{C}$; colour, 20 - 150 TCUs; TSS, $50 \mathrm{mg} / \mathrm{l}$; alkalinity, $400 \mathrm{mg} / \mathrm{l} ; \mathrm{Cl}, 250 \mathrm{mg} / \mathrm{l} ; \mathrm{DO}, 5 \mathrm{mg} / \mathrm{l} ; \mathrm{PO}_{4}^{3-}, 0.5-0.7$ $\mathrm{mg} / \mathrm{l} ; \mathrm{pH}, 5.5$ - 9.0; $\mathrm{NH}_{4}^{+}, 0.2$ - $4 \mathrm{mg} / \mathrm{l} ; \mathrm{Fe}, 0.2$ - $\left.2.0 \mathrm{mg} / \mathrm{l}\right)$ and NEMA standards (colour, 300 TCUs; Mg, 100mg/l; DO, 5mg/l; $\mathrm{PO}_{4}^{3-}$, $10 \mathrm{mg} / \mathrm{l} ; \mathrm{pH}, 6.0$ 8.0 ). On the other hand, the streams in the upstream registered the lowest values of the parameters i.e. Kibimba (temperature, $17.28^{\circ} \mathrm{C}$; EC, $31 \mu \mathrm{s} / \mathrm{cm}$; $\mathrm{PO}_{4}^{3-}, 0.24 \mathrm{mg} / \mathrm{l}$ ), Kasharara (colour, 15.17 TCU; TSS, $2.5 \mathrm{mg} / \mathrm{l} ; \mathrm{pH}, 6.23$; alkalinity, $19.67 \mathrm{mg} / \mathrm{l} ; \mathrm{DO}, 9.99 \mathrm{mg} / \mathrm{l} ; \mathrm{Mg}, 4.41 \mathrm{mg} / \mathrm{l} ; \mathrm{CaCO}_{3}, 23.17 \mathrm{mg} / \mathrm{l}$ ) and Karungu (turbidity, $7.02 \mathrm{mg} / \mathrm{l} ; \mathrm{Fe}, 0.12 \mathrm{mg} / \mathrm{l}$ ). Calcium carbonate hardness of the waters ranged from soft to excessively hard across the stream. The variations of the parameters detected in the streams in the downstream could reach adverse conditions if no intensive measures are taken to regulate the different anthropogenic activities within the catchment of river Rwizi.

\section{Keywords}

River Rwizi, Catchment, Water Quality, Physicochemical Parameters

\section{Introduction}

Safe water and sanitation are services of great concern globally and have been listed as number six among the recently established sustainable development goals (SDG) [1]. According to World Health Organisation, (WHO) approximately 748 million people, mostly from rural poor settings, cannot access improved water supply sources [2]. As a result, the poor communities find themselves with fewer options for water supply including natural tributaries like rivers and streams. Rivers and streams are very susceptible to contamination, because of their shallow aquifers [3] and therefore may not be safe. The water sources are often exposed to contamination from industrial and animal wastes which make them unfit for human and animal health. Hence it is important to carry out a study on the physicochemical composition of river Rwizi and its streams. In addition, the interactions of both the physical and chemical properties of water play a significant role in composition, distribution, abundance, movements and diversity of aquatic life forms [4] [5] [6] [7]. For instance, temperature, dissolved oxygen, $\mathrm{pH}$, turbidity, water transparency and current affect riverine fish ecology [8] and fish move away from alkaline waters when $\mathrm{pH}$ levels approach 9.06 - 10.0 [9].

River Rwizi is the main source of water for people and their livestock in South Western Uganda particularly in the districts of Mbarara and Sheema. The river 
is the main source of water for national water and sewerage cooperation (NWSC) that supplies piped water to the urban centres in the region. Communities around the river use the water for commercial and domestic purposes, including waste disposal. There are also extensive agricultural activities i.e. crop agriculture, livestock rearing and fish rearing carried around the catchment of river Rwizi [10] which have negatively impacted on the physico-chemical quality of its waters. Agricultural pollution emanates mainly from irrigation water and runoff water after rains, carrying fertilizers, pesticides, herbicide and faecal matter [11].

Different studies have been done on River Rwizi mainly for a small part of the River in Mbarara Municipality with results indicating higher physicochemical parameters of the river than the NEMA standards attributable to pollution from domestic, waste water, agricultural runoff and industrial effluents [12] [13]. However, little is known of the physico-chemical quality of the waters of the channels and streams entering into the river. Therefore, this study determined the physico-chemical parameters of selected streams and channels draining into river Rwizi along a spatial and seasonal gradient.

\section{Materials and Methods}

\subsection{Study Area}

\subsubsection{Geographical Location of River Rwizi and the Study Area}

River Rwizi located at an altitude between 1300 to 2170 (average of 1800) meters above sea level originates from the Buhweju hills and is approximately $55 \mathrm{~km}$ long [14] [15]. It flows eastwards eventually pouring its waters into Lake Victoria via a network of wetlands of the Kooki lakes (Mburo, Kachera, Nakivale, Kijanebarola) system [16]. River Rwizi catchment stretches across 10 districts in south-western Uganda and covers a total geographical area of approximately $8353 \mathrm{~km}^{2}$ comprising of land area $\left(7821 \mathrm{~km}^{2}\right)$, wetlands $\left(240 \mathrm{~km}^{2}\right)$, forests $(207$ $\left.\mathrm{km}^{2}\right)$ and open water area $\left(85 \mathrm{~km}^{2}\right)$ [17]. The wetlands in the catchment play an important role in capturing and storing water, and releasing it into the river channel over time. However most of these wetlands have been destroyed for the various agricultural activities.

The study was carried out in the districts of Buhweju, Sheema, Mbarara and Isingiro (Figure 1).

\subsubsection{Climate of the Study Area}

River Rwizi basin receives a mean annual rainfall of about $987 \mathrm{~mm}$. The catchment experiences a bi-modal annual distribution with two clear rainy seasons. The longest rainy season occurs from September to November, sometimes extending into December while the shortest season occurs between March and May [18]. The annual average rainfall received in Mbarara (middle area of the catchment) ranges between 690 and $870 \mathrm{~mm}$, and is $12 \%-30 \%$ less than the overall annual average for the catchment [10]. There is high temporal variability of up to $100 \mathrm{~mm}$ between the wettest and driest months. The maximum monthly 


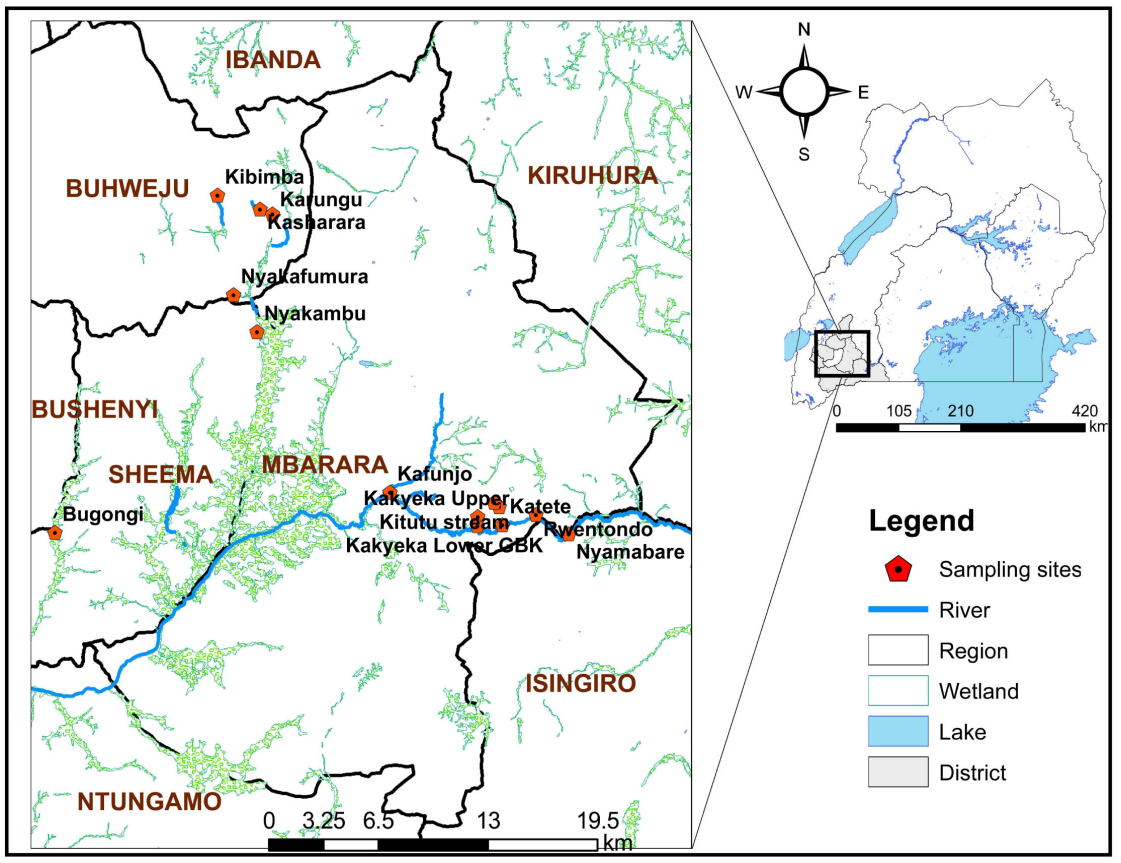

Figure 1. Map of Uganda showing the study location.

rainfall (MMR) is generally received in November averaging to $135 \mathrm{~mm}$. The maximum monthly rainfall in the shorter rainy season is received in April with an average of $131 \mathrm{~mm}$. July is the driest month, receiving only $34 \mathrm{~mm}$ of rainfall on average. There is significant spatial and temporal variation in the mean rainfall received across the catchment. For instance the average annual rainfall at Bushenyi a grommet station is $1216 \mathrm{~mm}$ while the value at Mbarara meteorological station is only $928 \mathrm{~mm}$ [10] [19] though the annual rainfall pattern is consistent over the catchment.

\subsubsection{Geology of the Study Area}

The geology of the upstream of the study area comprises of deep mountainous ridges with paucity of exposure, deep weathering and extensive regolith and dense vegetation [20] [21]. While the rest of the area is made up of the underlying rock, mainly the Precambrian rocks. The soils range from clay loams, sand loams to murram in most areas.

\subsection{Sampling}

\subsubsection{Choice of Sampling Sites}

Sampling sites were selected mainly according to the land use practices and according to type of pollution, point and non-point sources. Upstream and midstream were characterized by intensive agriculture and cattle rearing, while downstream was characterized by urbanization, industrialization and farming activities.

\subsubsection{Description of Sites}

The upstream section (Buhweju district), which is the source of River Rwizi, the 
following streams were sampled; Kasharara $\left(0.34765^{\circ} \mathrm{S}, 30.46295^{\circ} \mathrm{E}\right)$, Karungu $\left(0.35187^{\circ} \mathrm{S}, 30.4736^{\circ} \mathrm{E}\right)$, Kibimba $\left(0.33587^{\circ} \mathrm{S}, 30.42692^{\circ} \mathrm{E}\right)$ and Nyakafumura $\left(0.4199^{\circ} \mathrm{S}, 30.44055^{\circ} \mathrm{E}\right)$. The midstream section (Sheema district) the streams sampled included Nyakambu $\left(0.45117^{\circ} \mathrm{S}, 30.46035^{\circ} \mathrm{E}\right)$, and Bugongi $\left(0.62068^{\circ} \mathrm{S}\right.$, $30.28904^{\circ} \mathrm{E}$ ). The streams sampled in the downstream (Mbarara and Isingiro districts) were Kafunjo $\left(0.58667^{\circ} \mathrm{S}, 30.57325^{\circ} \mathrm{E}\right)$, Kakyeka GBK $\left(0.61505^{\circ} \mathrm{S}\right.$, $\left.30.64738^{\circ} \mathrm{E}\right)$, Kakyeka upper $\left(0.60729^{\circ} \mathrm{S}, 30.64764^{\circ} \mathrm{E}\right)$, Bus park $\left(0.59879^{\circ} \mathrm{S}\right.$, $\left.30.66571^{\circ} \mathrm{E}\right)$, Kitutu $\left(0.59529^{\circ} \mathrm{S}, 30.66169^{\circ} \mathrm{E}\right)$, Katete $\left(0.61417^{\circ} \mathrm{S}, 30.6685^{\circ} \mathrm{E}\right)$ and Rwentondo $\left(0.60559^{\circ} \mathrm{S}, 30.69697^{\circ} \mathrm{E}\right)$ as well as Nyamabare stream $\left(0.62182^{\circ} \mathrm{S}\right.$, $30.72487^{\circ} \mathrm{E}$ ), (Figure 1).

\subsubsection{Sample Collection}

Water samples were collected in clean plastic bottles. Sample bottles were completely filled and tightly secured. Water samples were analyzed within 5 hours from the time of collection and those not analyzed immediately were stored at $4^{\circ} \mathrm{C}$ and warmed to room temperature before tests were carried out [22].

A total of three hundred and thirty-six (336) water samples were purposively collected from the fourteen (14) streams in 2017. The sampling was done once a week for a period of six months, whereby three months (March, April and May) were in wet season and three months (June, July and August) were in dry season. From each site of the stream, water samples were collected in triplicates per sampling visit. All samples were collected from 8.00am to 12 noon periods of the day. The same procedures were repeated during the wet season. The three samples (triplicates) at each stream were collected from upstream, midstream and downstream. Below were the tests carried out on each parameter of water quality indicators.

\subsection{Physico-Chemical Analyses}

Physiochemical analyses were performed by using the standard methods of American Public Health Association [23] and standard operating manual [24].

\subsubsection{Temperature $\left({ }^{\circ} \mathrm{C}\right)$}

Temperature was measured in situ using a calibrated digital meter by dipping the electrode into water and waited until the reading stabilized and then recorded in ${ }^{\circ} \mathrm{C}$.

\subsection{2. $\mathrm{pH}$}

$\mathrm{pH}$ was measured in situ using a $\mathrm{pH} / \mathrm{EC}$ multimeter. The wet cap of the electrode was carefully removed, electrode rinsed with distilled water. Then the meter was switched on and electrode dipped in the water. The $\mathrm{pH}$ reading was left to stabilize and then recorded.

\subsubsection{Electrical Conductivity, EC ( $\mu \mathrm{s} / \mathrm{cm})$}

Electrical Conductivity (EC) was measured using a $\mathrm{pH} / \mathrm{EC}$ multimeter. The electrical conductivity cell was removed from the wet cap and rinsed with $0.01 \mathrm{~N}$ 
KCL solution, then followed by a portion of the sample to be tested. The cell/ electrode was then dipped in the water sample and the meter left to stabilize and EC reading then recorded in $\mu \mathrm{s} / \mathrm{cm}$.

\subsubsection{Dissolved Oxygen, DO (mg/l)}

Dissolved oxygen was done in situ using a calibrated dissolved oxygen digital meter by dipping the electrode into water and waited until the reading stabilized and then recorded in $\mathrm{mg} / \mathrm{L}$.

\subsubsection{Apparent Colour (TCUs)}

A DR 2010 spectrophotometer was used to measure apparent colour. The spectrophotometer was switched on and left to go through self-check. A selection of the stored programs was made and then scrolled to the colour parameter. Distilled water $(10 \mathrm{mls})$ was put into the sample cell and used to blank or zero the machine. The sample cell was then removed and emptied and $10 \mathrm{mls}$ of the water samples put in it. The sample cell was put in the spectrophotometer and option READ was presented. The value displayed on the screen was recorded in TCUs or Pt/Co as $1 \mathrm{TCU}=1 \mathrm{mg} / \mathrm{l} \mathrm{Pt} / \mathrm{Co}$ [25].

\subsubsection{Turbidity (NTUs)}

Turbidity was measured using Turbidimeter. The meter was first calibrated by inserting a turbidity standard tube containing a suspension of known turbidity, and then the Turbidimeter needle adjusted until it registers the valve. A $10 \mathrm{ml}$ of the sample was thoroughly shaken to remove all air bubbles and then poured into Turbidimeter and the READ button pressed. The reading was left to stabilize and read directly from the instrument scale and recorded in Nephelometric Turbidity Units (NTUs)

\subsubsection{Total Suspended Solids (mg/L)}

Total suspended solids were measured using Photometric Method (nonfilterable residue).

$500 \mathrm{ml}$ of sample was blended at high speed for exactly 2 minutes. The blended sample was poured into a $600 \mathrm{ml}$ beaker. The sample cell was filled with $25 \mathrm{ml}$ of tap water or demonized water and acted as blank, and this was placed in the cell holder. The sample cell was then tightly covered with the instrument cap, ZERO button was pressed and on the screen $0 \mathrm{mg} / \mathrm{L}$ TSS showed. The blended sample was stirred thoroughly and $25 \mathrm{~mL}$ was immediately poured into a sample cell, any gas was removed by swirling. The prepared sample was poured into the cell holder and tightly covered with the instrument cap. The READ button was pressed and the results were displayed on the screen in $\mathrm{mg} / \mathrm{L}$ [26].

\subsubsection{Total alkalinity $(\mathrm{mg} / \mathrm{l})$}

Water sample $(100 \mathrm{~mL})$ was put in an Erlenmeyer flask, 3 drops of methyl orange indicator solution was added to the flask. Sample was titrated with $0.02 \mathrm{~N}$ sulphilic acid, constantly swirling the flask content above a white surface until 
just after the colour of the flask content changed from yellow to red. The volume of titrant used was recorded and total Alkalinity was calculated as follows,

Total alkalinity as $\mathrm{mg} / \mathrm{L} \mathrm{CaCO}_{3}=\mathrm{A} \times \mathrm{N} \times 1000 \times 50 / \mathrm{mL}$ of sample.

where: $\mathrm{A}=\mathrm{mL} 0.02 \mathrm{NH}_{2} \mathrm{SO}_{4}$ used for methyl-orange end point. $\mathrm{N}=$ Normality of $\mathrm{H}_{2} \mathrm{SO}_{4}, 0.02 \mathrm{~N}$.

\subsubsection{Total Iron, Fe (mg/l)}

Total Iron was measured using a Hach Spectrophotometer, Model DR/2010. A $25 \mathrm{ml}$ of distilled water was put in the sample cell, also $25 \mathrm{ml}$ of sample put in the sample cell accordingly. $0.5 \mathrm{ml}$ of ferrozine reagents was added to each of sample cell shaken 1 and left to stand for 5 minute reaction time to lapse. The machine was zeroed using the blank. The ZERO button was pushed and the display showed $0.00 \mathrm{mg} / \mathrm{l} \mathrm{Fe}$. The prepared sample cell was cleaned and inserted into the cell holder. The wave length used was $562 \mathrm{~nm}$. The READ button was then pushed and results read in $\mathrm{mg} / \mathrm{L} \mathrm{Fe}$.

\subsubsection{Magnesium (Mg)}

Magnesium was measured using DR/2800 spectrophotometer, $25 \mathrm{ml}$ of water sample was put in a clean rinsed tube. The contents of one Ascorbic Acid powder pillow was added to each test tube swirled to mix. $1 \mathrm{ml}$ of PAN indicator solution was added to each sample and also swirled to mix, $560 \mathrm{~nm}$ wavelength was used. Readings was directly from the screen.

\subsubsection{Phosphate, $\mathrm{PO}_{4}^{3-}(\mathrm{mg} / \mathrm{l})$}

The water sample was filtered using $0.45 \mu \mathrm{m}$ Whatman GF/C filter paper. $25 \mathrm{ml}$ of whole filtered sample not exceeding a content of $15 \mathrm{ug} / 1$ into a $50 \mathrm{ml}$ stoppered volumetric flask. A blank and phosphate standard were also prepared. The blank and phosphate standard were treated in the same way as the sample. All were heated for 30 minutes in an autoclave at $120^{\circ} \mathrm{C}$ and cooled at room temperature. The colour reaction was made in the destruction bottles and $3 \mathrm{ml}$ of combined reagent was added and mixed well. Finally $1 \mathrm{ml}$ of ascorbic acid was added to each sample and mixed thoroughly. It was allowed to stand for $20 \mathrm{mi}-$ nutes for blue colour to develop. The concentration was measured in $\mathrm{mg} / \mathrm{Lat} 880$ $\mathrm{nm}$ wavelengths using the spectrophotometer CECIL 1000 and results read from the screen.

\subsubsection{Calcium carbonate $\left(\mathrm{CaCO}_{3}\right), \mathrm{mg} / \mathrm{l}$}

Calcium Carbonate was determined directly with Ethylene diaminetetra-Acetic Acid (EDTA). Using a measuring cylinder $100 \mathrm{mls}$ of water samples was transferred to a $250 \mathrm{ml}$ Erlenmeyer flask and I $\mathrm{ml}$ of $8 \mathrm{~N} \mathrm{NaOH}$ was added. Then the burette was filled to mark with $0.02 \mathrm{~N}$ EDTA acid. Murexide indicator was added of $0.1-1.2 \mathrm{~g}$. EDTA acid was added slowly from burette to one of the test portions in flask, and then mixing was thoroughly done by rotating flask. Continuously the colors in the flask were compared as the acid was added, and at the 
appearance of permanent purple colour in the test flask, acid was stopped from being added in. Results were reported in $\mathrm{mg} / \mathrm{l}$ calcium carbonate.

\subsubsection{Nitrate, $\mathrm{NO}_{3}(\mathrm{mg} / \mathrm{l})$}

Nitrate was tested using test strips by colorimetric method, water sample at $15^{\circ} \mathrm{C}$ - $25^{\circ} \mathrm{C}$ was put in the beaker and the test strip was immersed in it with both reaction zones for 1 second. The excess liquid was shacked off from the strip and after 1 minute determination with which color field on the label coincided most exactly on the reaction zone of the $\mathrm{NO}_{3}$. Then the results were read off correspondingly in $\mathrm{mg} / \mathrm{L}$.

\subsubsection{Ammonium, $\mathrm{NH}_{4}^{+}$(mg/l)}

Ammonium test was determined using test strip by colorimetric method. $5 \mathrm{ml}$ of water sample was put in plastic vessel and 10 drops of $\mathrm{NH}_{4}^{1-}$ was added, swirled for homogeneity. The reaction zone on test strip was immersed in the water sample for 3 seconds. The excess liquid was left to run off via the long edge of the strip on to an absorbent paper towel and after 10 seconds and the color was determined with color field on the label of the reaction zone which coincided most exactly. The corresponding results were read off in $\mathrm{mg} / \mathrm{l}$.

\subsubsection{Chloride, $\mathrm{Cl}$ (mg/l)}

Water samples were analyzed for chloride using colorimetric method. Water sample was put in a beaker and the reaction zones on a strip with was immersed sample at $15^{\circ} \mathrm{C}-25^{\circ} \mathrm{C}$ for 1 second. The excess liquid was Shacked off from the strip and after $1 \mathrm{~min}$, the color was determined on color row of the reaction zones which coincided most exactly. The corresponding results were read off in $\mathrm{mg} / \mathrm{l} \mathrm{Cl}$.

\subsection{Data Analysis}

Data on physico-chemical parameters (DO, colour, turbidity, TSS, Fe, $\mathrm{PO}_{1}^{3-}$, alkalinity, $\mathrm{Mg}, \mathrm{CaCO}_{3}$, temperature, $\mathrm{pH}, \mathrm{NH}_{4}^{+}, \mathrm{EC}, \mathrm{Cl}, \mathrm{NO}_{3}$ ) from the sampled streams/channels were summarized using descriptive statistics. The range, mean and coefficient of variation of the parameters from the studied streams are presented in Table 1. On the hand, the mean values of the parameters obtained from the streams/channels at the upstream, midstream and downstream sections of river Rwizi during the March to May and June to August sampling periods are presented using multiple bar graphs shown in Figure 2 and Figure 3. Variations in physicochemical parameters across the various sites (streams/channels) and stream sections were determined using Analysis of variance (ANOVA) test denoted by Fisher's (F) statistic as shown in Table 1 while the seasonal variation of the parameters was done by student $t$ test and are presented as narrative. Associations between the parameters were ascertained using Pearson correlation coefficient ( $r$ ) as shown in Table 2. Hypotheses tests were performed at 5\% level of significance. Data analysis was performed by the aid of Micosoft Excel ver. 2013 and SPSS Ver. 20 statistical packages. 
Table 1. Physico-chemical parameters at the various sites along river Rwizi.

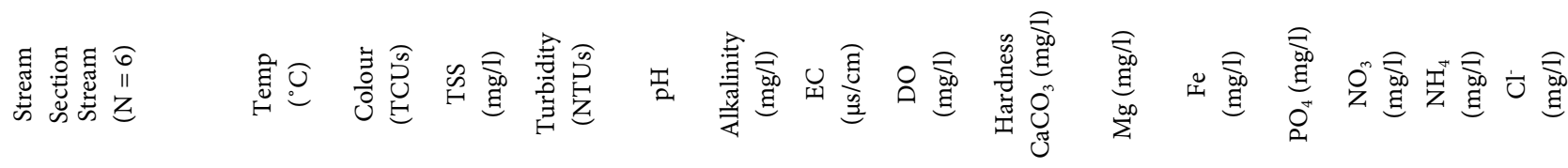

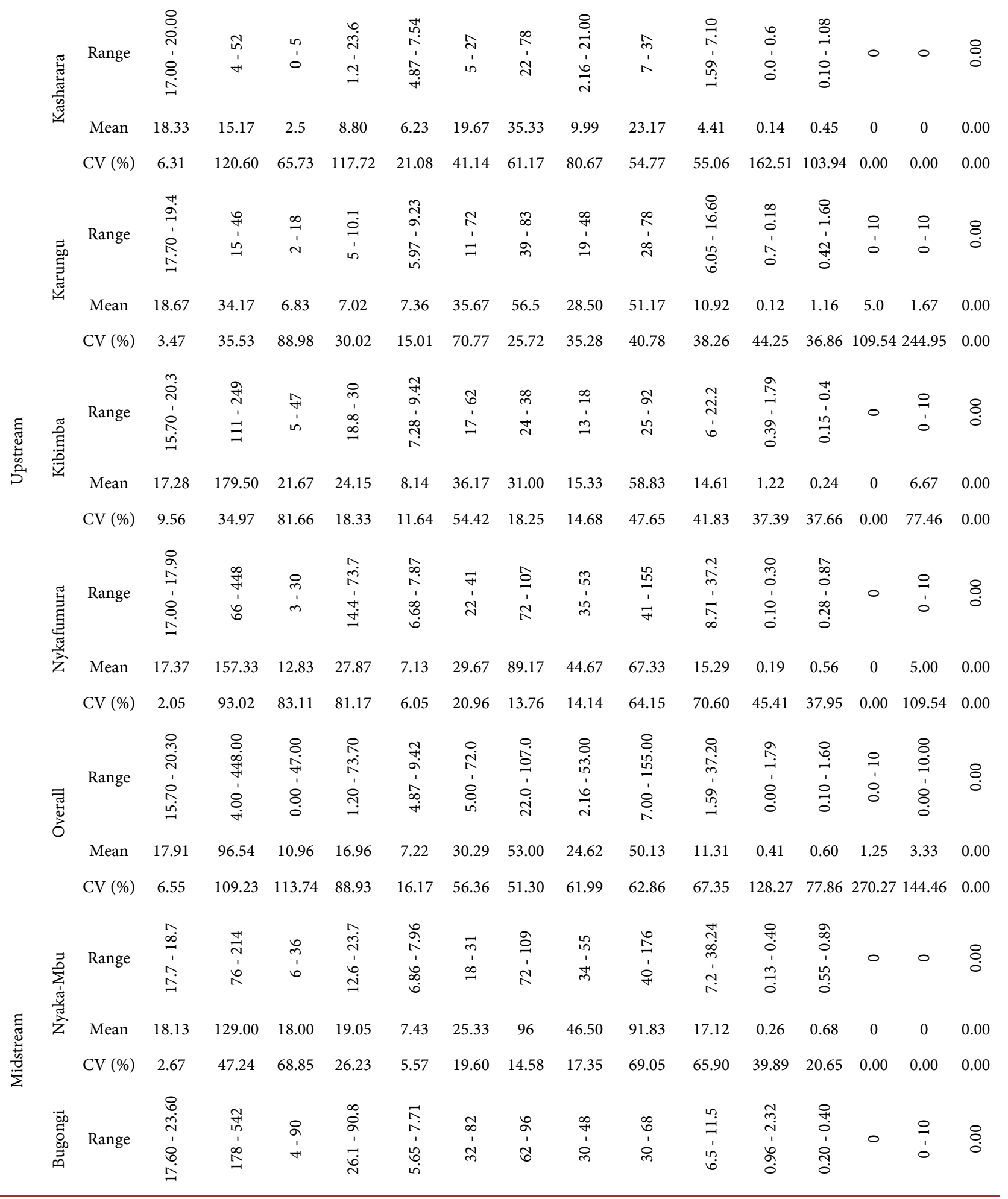




\section{Continued}

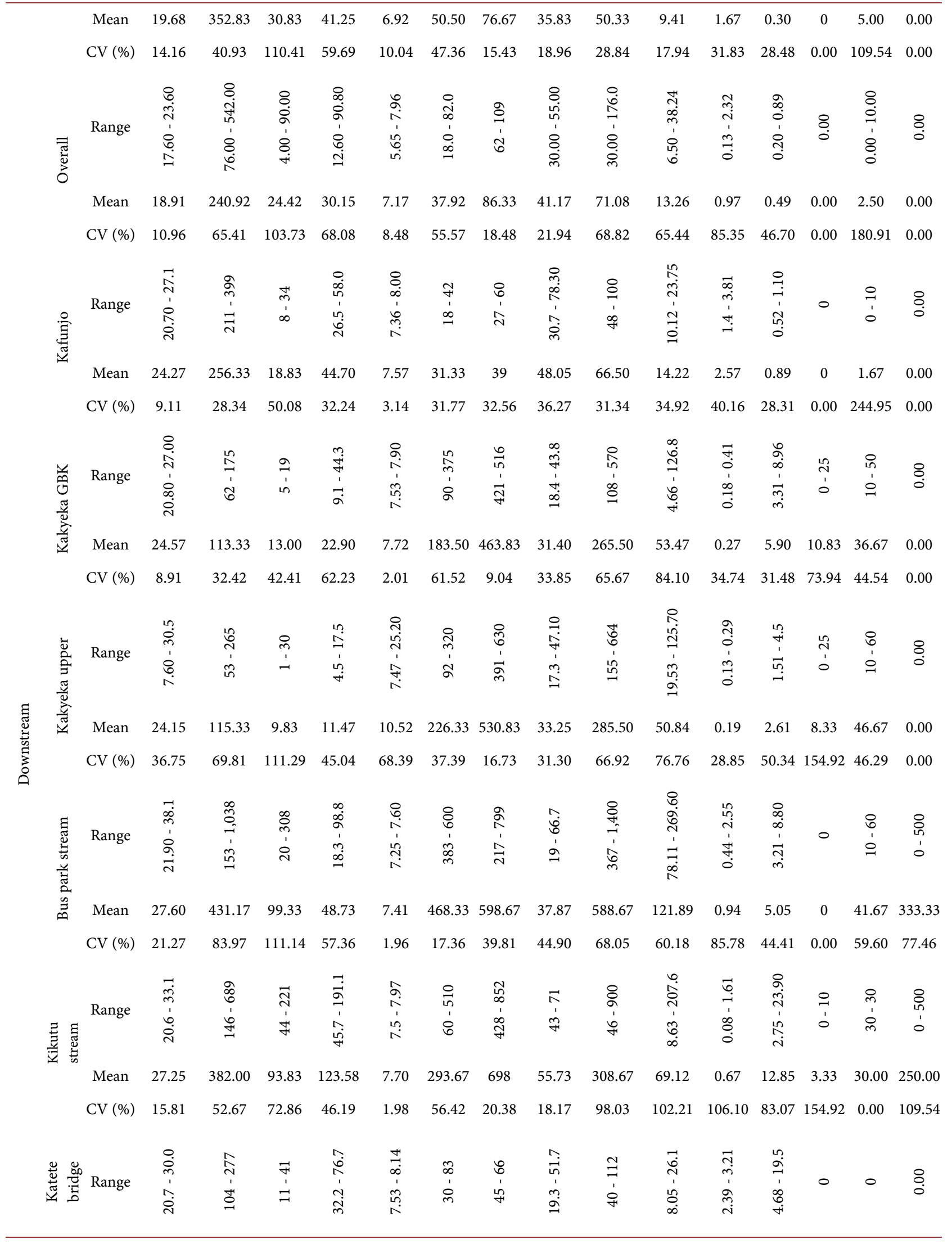




\begin{tabular}{|c|c|c|c|c|c|c|c|c|c|c|c|c|c|c|c|c|}
\hline & Mean & 25.05 & 227.17 & 20.67 & 54.85 & 7.74 & 57.17 & 56.33 & 37.83 & 61.50 & 13.89 & 2.84 & 10.53 & 0 & 0 & 0.00 \\
\hline & CV (\%) & 13.02 & 27.17 & 54.97 & 31.44 & 2.69 & 37.10 & 11.92 & 33.95 & 42.12 & 46.22 & 9.84 & 53.08 & 0.00 & 0.00 & 0.00 \\
\hline \multirow{3}{*}{ 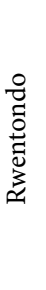 } & Range & $\begin{array}{l}\vec{N} \\
\stackrel{1}{1} \\
\tilde{n} \\
\stackrel{\sim}{1}\end{array}$ & 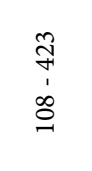 & $\begin{array}{l}\hat{m} \\
\vdots \\
a\end{array}$ & $\begin{array}{l}0 \\
\ddot{0} \\
\infty \\
1 \\
+1 \\
\infty\end{array}$ & 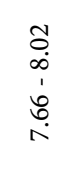 & $\begin{array}{l}\infty \\
\stackrel{1}{1} \\
1 \\
\infty \\
+\end{array}$ & $\begin{array}{l}\stackrel{\infty}{\infty} \\
\stackrel{N}{1} \\
1 \\
\infty \\
i n\end{array}$ & $\begin{array}{l}8 \\
\stackrel{8}{0} \\
1 \\
\stackrel{n}{3} \\
\text { in }\end{array}$ & $\begin{array}{l}\tilde{n} \\
\stackrel{1}{1} \\
\hat{6}\end{array}$ & 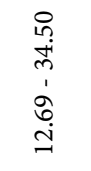 & $\begin{array}{l}\hat{n} \\
m \\
\dot{n} \\
\dot{m} \\
m\end{array}$ & $\begin{array}{l}\infty \\
\infty \\
\stackrel{n}{n} \\
1 \\
m \\
m \\
m\end{array}$ & $\begin{array}{l}0 \\
1 \\
0\end{array}$ & $\begin{array}{l}0 \\
1 \\
1\end{array}$ & $\stackrel{8}{\circ}$ \\
\hline & Mean & 23.50 & 251.00 & 21.67 & 48.55 & 7.92 & 78.83 & 126 & 43.92 & 93.67 & 20.35 & 3.44 & 8.81 & 6.67 & 6.67 & 0.00 \\
\hline & CV (\%) & 10.29 & 44.13 & 55.20 & 58.95 & 1.82 & 63.63 & 79.74 & 56.33 & 37.98 & 40.47 & 2.70 & 47.30 & 77.46 & 77.46 & 0.00 \\
\hline \multirow{3}{*}{ 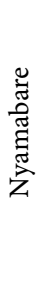 } & Range & $\begin{array}{l}\stackrel{8}{0} \\
\stackrel{i}{1} \\
1 \\
\dot{0} \\
\stackrel{i}{1}\end{array}$ & $\begin{array}{l}\stackrel{2}{n} \\
\ddot{1} \\
\stackrel{\infty}{0}\end{array}$ & $\begin{array}{l}\tilde{m} \\
\ddot{n} \\
\ddot{1}\end{array}$ & 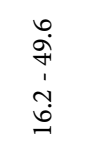 & 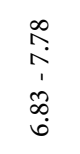 & $\begin{array}{l}\text { 우 } \\
1 \\
\text { o }\end{array}$ & $\begin{array}{l}\stackrel{\infty}{=} \\
\stackrel{1}{\prime}\end{array}$ & $\begin{array}{l}0 \\
\stackrel{1}{1} \\
\text { \& }\end{array}$ & $\begin{array}{l}8 \\
\text { 1 } \\
\text { ñ }\end{array}$ & 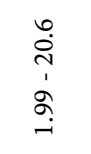 & $\begin{array}{l}\hat{\sigma} \\
\stackrel{-}{1} \\
\stackrel{1}{7} \\
\stackrel{0}{0}\end{array}$ & 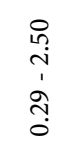 & 0 & 0 & $\stackrel{8}{0}$ \\
\hline & Mean & 21.90 & 237.83 & 20 & 35.65 & 7.31 & 34.67 & 106.50 & 51.83 & 50.50 & 7.90 & 0.98 & 1.43 & 0 & 0 & 0.00 \\
\hline & CV (\%) & 3.19 & 19.90 & 40.12 & 38.69 & 6.05 & 10.90 & 9.84 & 6.73 & 38.86 & 93.18 & 53.47 & 77.75 & 0.00 & 0.00 & 0.00 \\
\hline \multirow[t]{4}{*}{$\begin{array}{l}\overline{\text { ज्ञ }} \\
\text { ठें }\end{array}$} & Range & $\begin{array}{l}\stackrel{0}{1} \\
\infty \\
\infty \\
1 \\
0 \\
0 \\
1\end{array}$ & 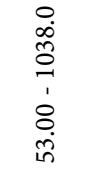 & $\begin{array}{l}0 \\
0 \\
0 \\
0 \\
1 \\
\dot{0} \\
\dot{0}\end{array}$ & 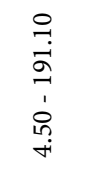 & $\begin{array}{l}\stackrel{N}{1} \\
\ddot{n} \\
1 \\
\\
0 \\
0\end{array}$ & $\begin{array}{l}8 \\
8 \\
1 \\
\infty \\
0\end{array}$ & $\begin{array}{l}\text { గ̂ } \\
\infty \\
1 \\
\hat{N}\end{array}$ & 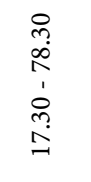 & $\begin{array}{l}8 \\
\stackrel{+}{1} \\
\text { 1 } \\
\text { n }\end{array}$ & 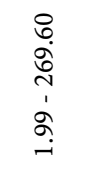 & $\begin{array}{l}\vec{\infty} \\
\dot{m} \\
1 \\
\infty \\
0 \\
0\end{array}$ & 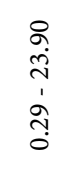 & $\begin{array}{l}\circ \\
\stackrel{0}{1} \\
1 \\
\dot{0} \\
\dot{0}\end{array}$ & $\begin{array}{l}8 \\
8 \\
8 \\
1 \\
\dot{8} \\
\dot{0}\end{array}$ & $\begin{array}{l}8 \\
0 \\
1 \\
8 \\
0 \\
0\end{array}$ \\
\hline & Mean & 24.79 & 253.64 & 37.15 & 48.80 & 7.99 & 171.73 & 327.40 & 42.49 & 215.06 & 43.96 & 1.49 & 6.01 & 3.65 & 20.42 & 74.47 \\
\hline & CV (\%) & 10.05 & 71.99 & 149.27 & 82.51 & 31.96 & 96.19 & 84.38 & 37.31 & 118.81 & 121.21 & 87.80 & 99.47 & 189.23 & 111.12 & 241.63 \\
\hline & $\mathrm{F}$ & 6.626 & 5.795 & 3.933 & 10.328 & 1.331 & 25.610 & 49.855 & 11.940 & 6.505 & 6.326 & 33.136 & 8.768 & 3.784 & 17.034 & 6.700 \\
\hline
\end{tabular}

\begin{tabular}{|c|c|c|c|c|c|c|c|c|c|c|c|c|c|c|c|}
\hline $\begin{array}{c}\text { ANOVA } \\
\text { (site) }\end{array}$ & $\mathrm{P}$ & $\begin{array}{l}\infty \\
\text { o } \\
\text { 亗 } \\
\infty \\
\infty \\
+\end{array}$ & $\begin{array}{l}\text { o } \\
\text { 1 } \\
\text { प్j } \\
\stackrel{+}{+} \\
\end{array}$ & $\begin{array}{l}n \\
0 \\
1 \\
1 \\
\infty \\
\infty \\
\infty\end{array}$ & $\begin{array}{l}\text { ㄱ. } \\
1 \\
\text { ㄸํㅇ } \\
2\end{array}$ & $\stackrel{\curvearrowright}{\stackrel{\sim}{0}}$ & 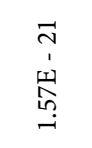 & $\begin{array}{l}\text { Pे } \\
1 \\
\dot{y} \\
\underset{+}{+} \\
\dot{+}\end{array}$ & $\begin{array}{l}\text { 옹 } \\
1 \\
\text { 핑 } \\
0 \\
i\end{array}$ & $\begin{array}{l}\infty \\
0 \\
1 \\
\text { 명 } \\
b \\
0\end{array}$ & $\begin{array}{l}\text { 오 } \\
1 \\
\text { 퐁 } \\
\text { 울 }\end{array}$ & $\begin{array}{l}\stackrel{2}{a} \\
1 \\
1 \\
\hat{1} \\
\stackrel{0}{0}\end{array}$ & $\begin{array}{l}0 \\
1 \\
1 \\
0 \\
\infty \\
i \\
i\end{array}$ & $\begin{array}{c}+ \\
1 \\
1 \\
\infty \\
\infty \\
\\
-1\end{array}$ & \begin{tabular}{l}
$A$ \\
1 \\
1 \\
\multirow{1}{1}{} \\
$\infty$ \\
$\infty$
\end{tabular} \\
\hline & F & 35.271 & 7.929 & 2.908 & 7.947 & 1.498 & 12.435 & 16.11 & 11.940 & 6.713 & 6.301 & 8.046 & 14.655 & 2.839 & 10.074 \\
\hline
\end{tabular}

ANOVA

(Stream

section)

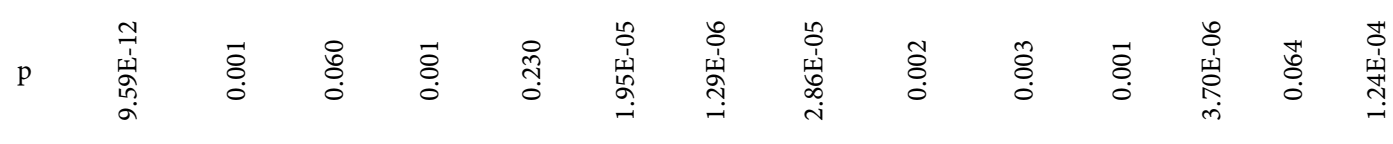

$\begin{array}{llllllllllllllll}\text { EPA standard [29] } & 25 & 20-150 & 50 & - & 5.5-9.0 & 400 & 1000 & 5 & - & -2 & -2.00 .5-0.7 & 50 & 0.2-4 & 250\end{array}$

$\begin{array}{lllllllllllllllll}\text { NEMA standard [30] } & 20-35 & 300 & 100 & 300 & 6.0-8.0 & - & - & 5 & - & 100 & 10 & 10.0 & - & - & 500\end{array}$

$\mathrm{CV}-$ Coefficient of variation.

Table 2. Pearson's correlation (r) matrix of the physico-chemical parameters in the study sites.

\begin{tabular}{|c|c|c|c|c|c|c|c|c|c|c|c|c|c|c|}
\hline $\begin{array}{l}\text { Parameters } \\
\qquad(\mathrm{N}=83)\end{array}$ & Colour & TSS & Turbidity & $\mathrm{pH}$ & Alkalinity & EC & DO & $\mathrm{Mg}$ & $\mathrm{CaCO}_{3}$ & Iron & $\mathrm{Cl}$ & $\mathrm{PO}_{4}^{3-}$ & $\mathrm{NO}_{3}$ & $\mathrm{NH}_{3}$ \\
\hline Temp & 0.17 & 0.12 & $0.40^{* *}$ & $-0.28^{\star *}$ & $0.50^{* *}$ & $0.49^{* *}$ & $0.25^{\star}$ & $0.35^{\star *}$ & $0.36^{* *}$ & $0.24^{*}$ & $0.32^{* *}$ & $0.33^{* *}$ & $0.37^{\star *}$ & $0.34^{* *}$ \\
\hline Colour & & $0.82^{* *}$ & $0.64^{* *}$ & 0.003 & $0.42^{* *}$ & $0.31^{*}$ & $0.37^{* *}$ & $0.37^{* *}$ & $0.34^{*}$ & $0.40^{* *}$ & $0.40^{* *}$ & $0.39^{* *}$ & -0.15 & $0.24^{*}$ \\
\hline TSS & & & $0.59^{* *}$ & -0.007 & $0.55^{\star *}$ & $0.51^{\star *}$ & $0.24^{*}$ & $0.46^{* *}$ & $0.44^{* *}$ & 0.11 & $0.54^{* *}$ & $0.40^{* *}$ & -0.12 & $0.36^{* *}$ \\
\hline Turbidity & & & & -0.025 & $0.45^{* *}$ & $0.37^{* *}$ & $0.34^{* *}$ & 0.17 & 0.13 & $0.32^{* *}$ & $0.42^{* *}$ & $0.45^{\star *}$ & 0.02 & 0.17 \\
\hline
\end{tabular}




\begin{tabular}{|c|c|c|c|c|c|c|c|c|c|c|}
\hline $\mathrm{pH}$ & 0.19 & 0.17 & 0.002 & 0.03 & 0.07 & 0.006 & -0.02 & 0.10 & -0.03 & $0.33^{* *}$ \\
\hline Alkalinity & & $0.91^{\star *}$ & 0.14 & $0.64^{* *}$ & $0.64^{* *}$ & -0.13 & $0.64^{\star *}$ & $0.47^{\star \star}$ & $0.24^{\star}$ & $0.73^{* *}$ \\
\hline EC & & & 0.19 & $0.62^{* *}$ & $0.63^{\star *}$ & $-0.25^{\star}$ & $0.67^{\star \star}$ & $0.37^{\star \star}$ & $0.34^{\star *}$ & $0.76^{\star *}$ \\
\hline DO & & & & 0.11 & 0.11 & 0.17 & 0.07 & $0.28^{* *}$ & -0.06 & 0.10 \\
\hline $\mathrm{Mg}$ & & & & & $0.92^{* *}$ & -0.15 & $0.50^{* *}$ & $0.33^{* *}$ & 0.09 & $0.50^{* *}$ \\
\hline $\mathrm{Ca}$ & & & & & & -0.17 & $0.49^{* *}$ & $0.32^{\star *}$ & 0.08 & $0.52^{\star *}$ \\
\hline Iron & & & & & & & -0.002 & $0.23^{*}$ & -0.05 & $-0.22^{\star}$ \\
\hline $\mathrm{Cl}$ & & & & & & & & 0.06 & 0.02 & $0.33^{* *}$ \\
\hline $\mathrm{PO}_{4}$ & & & & & & & & & 0.02 & $0.25^{\star}$ \\
\hline $\mathrm{NO}_{3}$ & & & & & & & & & & $0.36^{* *}$ \\
\hline
\end{tabular}

${ }^{\star}$ Correlation is significant at the 0.05 level (2-tailed); ${ }^{* *}$ Correlation is significant at the 0.01 level (2-tailed).

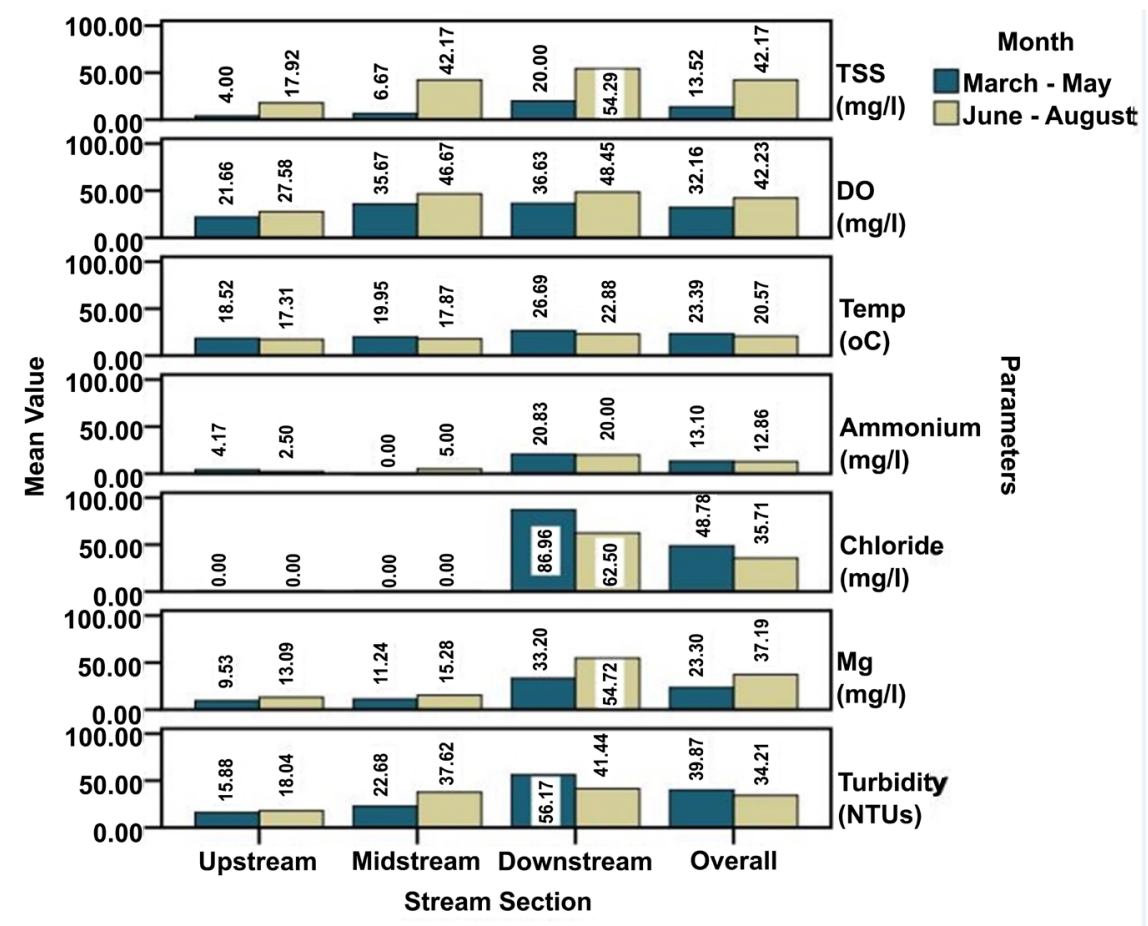

Figure 2. Summary of the physico-chemical parameters in the stream entering R. Rwizi in S/W Uganda between March and August 2017.

\section{Results and Discussion}

\section{Physico-Chemical Parameters in the Streams and Channels Draining into River Rwizi}

\section{1) Temperature}

Temperature is the measure of heat expressed in degrees Celsius or degrees Fahrenheit [27]. Temperature is vital to aquatic organisms because they depend on certain temperature ranges for their optimal health. Temperature also affects many other parameters in water which include dissolved oxygen, types of plants 

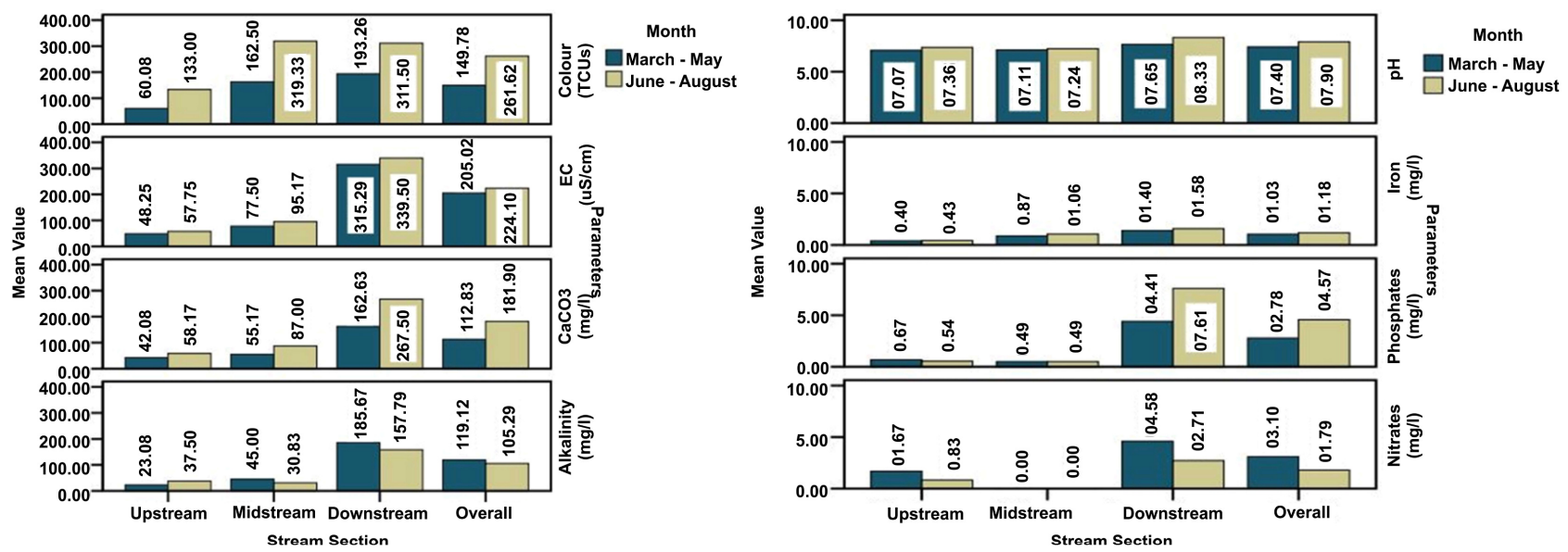

Figure 3. Summary of the physico-chemical parameters in the stream section entering R. Rwizi in S/W Uganda between March and August 2017.

and animals present and the susceptibility of organisms to parasites, pollution and disease [28].

There was low variability of temperature within the sampling sites in the upstream $(\mathrm{CV} ; 2.05 \%-6.31 \%)$ with the mean values ranging from $17.28^{\circ} \mathrm{C}$ to $18.67^{\circ} \mathrm{C}$ in Kibimba and Karungu respectively (Table 1 ). The variability of temperature within the sites was a bit higher in the midstream (CV; $2.67 \%-14.16 \%)$ and the mean temperature fluctuated from $18.13^{\circ} \mathrm{C}$ to $19.68^{\circ} \mathrm{C}$ registered in Nyakambu and Bugongi respectively. The temperature values in all the sites at the upstream and midstream were below the EPA guideline temperature $\left(25^{\circ} \mathrm{C}\right)$ of quality water [29] and NEMA permissible temperature range $\left(20^{\circ} \mathrm{C}-35^{\circ} \mathrm{C}\right)$ of waste water [30]. The within site variation of temperature was higher in the downstream (CV; 3.19\% - 36.75\%) with also higher mean temperature values ranging from $21.90^{\circ} \mathrm{C}$ (Nyamabare) to $27.60^{\circ} \mathrm{C}$ (Bus park stream). Temperature values in the bus park stream $\left(27.60^{\circ} \mathrm{C}\right)$, Kikutu stream $\left(27.25^{\circ} \mathrm{C}\right)$ and Katete bridge $\left(25.05^{\circ} \mathrm{C}\right)$ were higher than the EPA guideline value while the rest of the streams downstream had temperature values within the standard EPA value. On the other hand, the temperature values of the streams in the downstream were within the NEMA temperature range.

Generally, the temperature values were significantly different among the sampling sites $(\mathrm{p}<0.05)$ with Bus park stream recording the highest temperature $\left(27.60^{\circ} \mathrm{C}\right)$ while Kibimba stream had the least temperature $\left(17.28^{\circ} \mathrm{C}\right)$. The overall mean temperature values were significantly $(\mathrm{p}<0.05)$ highest downstream, followed by midstream and the least in the upstream (Table 1). Temperature of the streams were also significantly higher $(\mathrm{t}=2.80, \mathrm{p}=0.006)$ during the March-May study period than the June-August sampling period (Figure 2). The variation is mainly related with the temperature of the atmosphere and the weather condition [31]. River water temperature during dry season ranged from 16.4 - 17.3 minimum to 28.8 - 28.3 maximum according to the 2017 Mbarara meteorological station report and these changes were relatively uncertain. Ac- 
cordingly, most sites in the study did not demonstrate a consistent increase or decrease in water temperature during dry season months with annual probabilities of increase in water temperature varying over time as was similar to the findings of Wagner et al. [32].

Bus park and Kituntu streams both in downstream had the highest and the second highest temperature values possibly attributed to the increased human activities taking place within the two places. Kituntu had a bakery plant and the water from the plant is poured direct to the river which raised the temperature. Bus park is situated in a heavily populated slum area of Mbarara municipality characterized by different activities taking place which generate a lot of urban wastewater with high potential to increase the temperature of the stream. Also according to Cooper [33] the alteration of riparian vegetation may alter radiative heat exchanges and the occurrence of different hydrological conditions could bring about the temperature changes in the two sites.

\section{2) Colour}

Color in water is normally due to the presence of colored organic matter, associated with the humus part of soil and vegetation, presence of minerals especially iron and other metals occurring as natural impurities and corrosive products [17] [34]. Color can also be caused by industrial or municipal contamination and is usually a problem with surface waters.

The colour of the streams within the sampling sites varied greatly in the upstream (CV; 34.97\% - 120.60\%) with the lowest mean value (15.17 TCUs) recorded in Kasharara while the highest mean colour (179.50 TCUs) was in Kibimba (Table 1). The colour of the stream in all the sampling sites upstream were within the NEMA permissible colour of 300 TCUs. Only Karungu stream in the upstream recorded colour within the EPA guideline range of 20 - 150 TCUs. Kibimba and Nyakafumura streams had colours beyond the EPA guideline range while Kasharara stream had colour below the EPA standard range. The within site variation of colour was relatively low $(40.93 \%-47.24 \%)$ in the midstream with higher mean colour ranging from 129.00 TCUs in Nyakambu to 352.83 TCUs in Bugongi. The colour of the stream at Nyakambu was within the EPA and NEMA guidelines while stream colour in Bugongi was higher than the two standards. The within sample variability of colour of the stream was slightly high in the downstream $(\mathrm{CV} ; 19.90 \%$ - 83.97\%) with very high mean values ranging from 113.33 TCUs (Kakyeka GBK) to 431.17 TCUs (Bus park stream). The stream colour in Bus park stream and Kikutu stream were much higher than the NEMA standard while the rest of the sites had colors within the NEMA guideline. Only Kakyeka GBK and Kakyeka upper streams had colours within the EPA standard range while the rest of the streams in the downstream had colours much beyond the EPA guideline range.

On overall, the stream colour significantly varied across the sampling sites of the stream $(\mathrm{p}<0.05)$. Bus park stream also recorded the highest colour while Kasharara had the lowest colour. The water colour was significantly highest in 
the downstream, followed by midstream and finally upstream $(\mathrm{p}<0.05)$. This is associated with the disposal of municipal wastes and industrial effluents which end up into the existing streams and channels in the Municipality including the Bus park stream.

The colour of the stream (Figure 2) was significantly higher $(t=3.083, p=$ 0.003) during the June-August sampling period than the March-May period. This is caused by the different activities like sand mining, high demand of water for human use and cattle especially during the dry season that end up polluting the water. Some spells of erratic rainfall received during the June-August sampling period (dry season) due to climate change possibly carried a lot of suspended particles into the streams with high potential to colour the streams. According to EPA [29], the highest colour levels in rivers occur during the first flood after a dry season where accumulated deposits of decaying leaves and debris are swept up into the rainwater flow which release highly colouring matter. While in the wet season the water flow is first and clears quickly and the level of water level is high hence making it less prone to contamination [35]. The relatively high apparent color was due to surface runoff of some particulate matter especially from gardens within the watershed causing high turbidity and total iron content in the water [34]. This is supported by the overall significant positive correlation of apparent colour with turbidity and total iron (Table 2). Water color is attributed to the presence of minerals mainly iron as well as eroded soil.

\section{3) Total Suspended Solids (TSS)}

Total suspended solids (TSS) refer to solid matter suspended in water and waste water and it determines the general nature of water quality [36] [37]. It thus affects diverse fish population. There was relatively high variability of TSS within the sampling sites in the upstream (Table 1) (CV; 65.73\% - 88.98\%) with low mean TSS values ranging from $2.5 \mathrm{mg} / \mathrm{l}$ (Kasharara) to $21.67 \mathrm{mg} / \mathrm{l}$ (Kibimba). The variation of TSS within site was higher in the midstream (CV; $68.85 \%$ 110.41\%) with yet higher mean TSS values fluctuating between $18.00 \mathrm{mg} / \mathrm{l}$ (Nyakambu) and $30.83 \mathrm{mg} / \mathrm{l}$ (Bugongi). The TSS in both the upstream and midstream were within the NEMA $(100 \mathrm{mg} / \mathrm{l})$ and EPA $(50 \mathrm{mg} / \mathrm{l})$ standard values. The within site variability of TSS in the downstream was still relatively high (CV; $40.12 \%$ - 111.29\%). The downstream also recorded higher mean TSS varying from $9.83 \mathrm{mg} / \mathrm{l}$ (Kakyeka upper) to $99.33 \mathrm{mg} / \mathrm{l}$ (Bus park stream). All the sampling sites downstream had TSS values below the NEMA standard. Only Bus park and Kikutu streams had TSS above the EPA standard value while the TSS in the rest of streams are below the EPA guideline value.

Similarly, TSS significantly differed across all the sampling sites $(\mathrm{p}<0.05)$ with the Bus park stream recording the highest levels of TSS while Kashara also had the least TSS level. High waste generation in Mbarara town is also blamed for the increased TSS amounts in the Bus park stream. On overall, the mean total suspended solids (TSS) did not show any significant variation $(p>0.05)$ in the upstream, midstream and the downstream (Table 1) sections of the river. 
This is attributed to the uniform generation of particulate matter in all the stream sections. There are a lot of agricultural activities (crop agriculture, livestock rearing, fish rearing) in the upstream and midstream sections of the river [15] [38] which deposit high amounts of suspended particles in the river while wastes generated from Mbarara municipality are the main contributors of suspended particles in the downstream of the river.

Worth noting is that the June to August sampling period also recorded significantly $(t=3.079, p=0.003)$ higher total suspended solids than the March to May period (Figure 2). This is attributed to the erratic rains received during these months which carried suspended soil particles into the river.

\section{4) Turbidity}

Turbidity is the measure of the clarity or cloudiness of water. It is mainly caused by the presence of suspended solids and colloidal matter for example clay, silt, organic and inorganic matter, plankton, plus other microscopic organisms [37]. It may be due to eroded soil caused by dredging or due to the growth of micro-organisms. From Table 1, there was high variability of turbidity within sampling site in the upstream (CV; 18.33\% - 117.72\%) with the mean turbidity ranging from 7.02 to 27.87 NTUs in Karungu and Nyakafumura respectively.

The variability of turbidity was a low in the midstream (CV; $26.23 \%-59.69 \%)$ though the mean turbidity values were higher varying from 19.05 NTUs (Nyakambu) to 41.25 NTUs (Bugongi). The within site variability of turbidity was also relatively high downstream (CV; $31.44 \%-62.23 \%)$. The mean turbidity values downstream were still higher fluctuating between 11.47NTUs (Kakyeka upper) to 123.58 NTUs (Kikutu stream). All the streams in the study areas had turbidity values lower than the NEMA permissible value for wastewater (300 NTUs). There was also a significant variation of turbidity $(\mathrm{p}<0.05)$ across the various channels/streams with the most turbid being Kikutu stream while least turbid was Karungu stream. Turbidity values were significantly highest in the downstream, followed by midstream and lowest in the upstream sections of the river (Table 1). The March-May sampling period recorded slightly higher turbidity than the June to August months though the difference was insignificant $(\mathrm{t}$ $=0.735, \mathrm{p}=0.465$ ).

The highest values of turbidity downstream are attributed to the emission of coloured particles and metallic materials into the streams especially those generated from Mbarara municipality from paints and metal works etc. The significant positive correlation of turbidity and total iron (Table 2) supports the fact that turbidity increases with the release of iron and other metals [34] [39].

\section{5) $\mathrm{pH}$}

The $\mathrm{pH}$ of water is the measure of hydrogen ion concentration [34]. It expresses the intensity of acidity or alkalinity of an aquatic environment [31]. The $\mathrm{pH}$ of water is very important to living organisms as most of biological processes occur only within a narrow $\mathrm{pH}$ range [9]. The within site variability of $\mathrm{pH}$ was relatively low in the upstream (CV; 6.05\% - 21.08\%) with mean $\mathrm{pH}$ values fluc- 
tuating from 6.23 (Kasharara) and 8.14 (Kibimba) (Table 1). Similarly, the variation of $\mathrm{pH}$ was slightly low midstream (CV; 5.57\% - 10.04\%) with mean $\mathrm{pH}$ ranging from 6.92 (Bugongi) to 7.43 (Nyakambu). The within site variability of $\mathrm{pH}$ was a bit higher downstream $(\mathrm{CV} ; 1.82 \%-68.39 \%)$ and the mean $\mathrm{pH}$ values ranged from 7.31 to 10.52 at Nyamabare and Kakyeka upper respectively. Only Kakyeka upper stream in the downstream had mean $\mathrm{pH}$ value higher than the EPA (5.5 - 9.0) and NEMA (6.0 - 8.0) guideline values while the rest of the streams had mean $\mathrm{pH}$ values within the guideline values.

On overall, there was no significant variation of mean $\mathrm{pH}$ values across the sampling sites and the three stream sections i.e. upstream, midstream and downstream ( $\mathrm{p}>0.05$ ) as well as during the March-May and June-August sampling periods $(t=1.091, p=0.279)$. This points to the relative uniformity of the conditions at the sampling points and during the sampling period.

\section{6) Alkalinity}

Alkalinity is a neutralization reaction and in natural waters is primarily due to the salts of weak or strong bases [19]. Alkalinity is entirely due to hydroxide, carbonate or bicarbonate ions in water. As shown in Table 1, there was relatively high within site variability of alkalinity in the upstream (CV; 20.96\% - 70.77\%) with low mean alkalinity values ranging from $19.67 \mathrm{mg} / \mathrm{l}$ (Kasharara) to 36.17 $\mathrm{mg} / \mathrm{l}$ (Kibimba). The variation of alkalinity within site was a bit low in the midstream (CV; 19.60\% - 47.36\%) with slightly higher mean alkalinity values fluctuating between $25.33 \mathrm{mg} / \mathrm{l}$ (Nyakambu) and $50.50 \mathrm{mg} / \mathrm{l}$ (Bugongi). Furthermore, the within site variability of alkalinity in the downstream was relatively high (CV; 10.90\% - 63.63\%). The downstream recorded much higher mean alkalinity ranging from $31.33 \mathrm{mg} / \mathrm{l}$ (Kafunjo) to $468.33 \mathrm{mg} / \mathrm{l}$ (Bus park stream). Only Bus park stream in the downstream had mean alkalinity higher than the EPA guideline value $(400 \mathrm{mg} / \mathrm{l})$ while the rest of the streams had mean alkalinity values below the guideline value.

In general, alkalinity significantly differed across the sampling sites $(\mathrm{p}<0.05)$ with the bus park recording the highest value and Kasharara had the lowest value. On overall, the mean alkalinity of the stream was significantly more in the downstream followed by the midstream and finally the upstream $(\mathrm{p}<0.05)$. Much as the alkalinity was slightly higher during the March-May sampling period than the June-August period $(t=0.644, p=0.529)$, the difference was insignificant $(\mathrm{t}=0.442, \mathrm{p}=0.660)$.

The higher values of alkalinity downstream in both seasons followed by midstream was due to discharge of sewage and domestic solid wastes from Mbarara municipality concurrent with the findings of the research done by [31] [40]. Also the hydroxides, carbonates and bicarbonates, food residue do contribute to variation of alkalinity. There was also a significant positive correlation of alkalinity with $\mathrm{Mg}, \mathrm{CaCO}_{3}, \mathrm{Cl}$, phosphates, nitrates and ammonia (Table 2) which are either strong bases or salts of weak and strong bases.

However, the alkalinities of the streams were generally low and poorly buf- 
fered the $\mathrm{pH}$ of the streams thus making them liable to $\mathrm{pH}$ reduction under acidic environment. This further explains why the $\mathrm{pH}$ values of most of the streams were slightly low and close to neutral. According to EPA [29], a poorly-buffered water has a low or very low alkalinity and is susceptible to $\mathrm{pH}$ reduction by acid rain. The positive correlation of alkalinity and $\mathrm{pH}$ though statistically insignificant mean that low $\mathrm{pH}$ of the streams occurs under low alkalinity as a result of poor buffering. Moreover, [37] obtained a slightly acidic $\mathrm{pH}$ (5.80 6.70) for freshly fallen rainwater in Mbarara Municipality and this acidic rainwater possibly contributes to the relatively low $\mathrm{pH}$ of most of the streams downstream.

\section{7) Electrical Conductivity (EC)}

Conductivity is a measure of water's the capacity to convey electric current and is a useful parameter for assessment of the water purity [29] [34]. Conductivity is directly related to the concentration of ionized substance in the water [19]. Dissolved solids such as calcium, chloride, and magnesium in water samples conduct the electric current through water [34] [41].

There was relatively high variability of electrical conductivity (EC) within site in the upstream (CV; $13.76 \%-61.17 \%)$ with the mean EC ranging from 31.00 to $89.17 \mu \mathrm{s} / \mathrm{cm}$ in Kibimba and Nyakafumura respectively (Table 1 ). The variability of EC was a bit low in the midstream (CV; 14.58\% - 15.43\%) though the mean turbidity values were higher ranging from $76.67 \mu \mathrm{s} / \mathrm{cm}$ (Bugongi) to $96.00 \mu \mathrm{s} / \mathrm{cm}$ (Nyakambu). The within site variability of EC was relatively high downstream (CV; 9.04\% - 79.74\%). The mean EC values downstream were much higher fluctuating between $39 \mu \mathrm{s} / \mathrm{cm}$ (Kafunjo) to $698 \mu \mathrm{s} / \mathrm{cm}$ (Kikutu stream). The EC of all the streams were lower than the EPA standard value of $1000 \mu \mathrm{s} / \mathrm{cm}$.

There was generally a significant variation of electrical conductivity $(\mathrm{p}<0.05)$ across the various sampling sites of the stream. Kikutu stream had the highest EC value and Kibimba stream had the least. The downstream section of the stream recorded significantly higher electrical conductivity values followed by the midstream and finally the upstream section. The stream registered slightly higher electrical conductivity during the June-August sampling period than the March-May sampling period but the differences were insignificant $(t=0.353, p$ $=0.725$ ).

The higher values for EC in the trend of downstream to midstream could be associated with heavy deposition of metal irons from urban and industrial areas into the river through surface runoffs, channels and sewage effluents [34]. The significant positive correlation between $\mathrm{EC}$ and $\mathrm{Mg}, \mathrm{CaCO}_{3}, \mathrm{Cl}, \mathrm{PO}_{4}, \mathrm{NO}_{3}, \mathrm{NH}_{4}^{+}$ (Table 2) supports the fact that dissolved solids such as calcium, chloride, magnesium as well as other ionized substances in water samples are responsible for electrical current through water [19] [34] [41]. These ions possibly became more concentrated during the relatively dry June to August sampling period compared to the wet March to May sampling period.

This is further supported by the significant positive correlation of EC and 
temperature $(\mathrm{r}=0.49, \mathrm{p}<0.01)$ as shown in Table 2. EPA [29] found out that conductivity increases with temperature at a rate of about 2 per cent per degree $\mathrm{C}$ rise.

\section{8) Dissolved Oxygen (DO)}

Oxygen is an important gas for most aquatic organisms because it is needed for respiration [19] [36]. Dissolved oxygen (DO) is also an essential water quality parameter as well as an index of physical and biological process going on in water which favors the solubility of oxygen [42]. The average value of DO levels (4$6.5 \mathrm{mg} / \mathrm{l}$ ) indicates the average quality of river water [43].

The within sample DO in the stream greatly varied in the upstream $(\mathrm{CV}$; $14.14 \%-80.67 \%)$ with the lowest mean value $(9.99 \mathrm{mg} / \mathrm{l})$ recorded in Kasharara while the highest $(44.67 \mathrm{mg} / \mathrm{l})$ was in Nyakafumura (Table 1). The within site variation of dissolved oxygen was relatively low $(17.35 \%-18.96 \%)$ in the midstream but the mean values of the dissolved oxygen of the stream were higher ranging from $35.83 \mathrm{mg} / \mathrm{l}$ in Bugongi to $46.50 \mathrm{mg} / \mathrm{l}$ in Nyakambu. The within sample variability of DO in the stream was slightly high in the downstream (CV; $6.73 \%-56.33 \%$ ) with very high mean values ranging from $31.40 \mathrm{mg} / \mathrm{l}$ (Kakyeka GBK) to $55.73 \mathrm{mg} / \mathrm{l}$ (Kikutu stream). The mean dissolved oxygen concentrations in all the sampled streams were greater than the EPA and NEMA guideline value of $5 \mathrm{mg} / \mathrm{l}$.

On overall, dissolved oxygen content in the stream significantly varied across the sampling sites of the streams $(\mathrm{p}<0.05)$ with Kikutu stream registering the highest DO levels while Kasharara had the least. Dissolved oxygen concentrations were also significantly highest in the downstream followed by the midstream and finally the upstream $(\mathrm{p}<0.05)$. The sampling period, June-August registered significantly higher DO than the March-May period $(\mathrm{t}=2.867, \mathrm{p}=$ 0.005). DO values indicate lateral, spatial and seasonal changes depending on industrial, human and thermal activities [31]. The upstream had the least DO possibly due to decomposition of organic matter from the more intensive agricultural activities practiced upstream compared to the midstream and downstream. This is consistent with Lukubye and Andama [37] who obtained low DO in a shallow well situated $1 \mathrm{~m}$ from croplands and attributed it to increased decomposition of organic material from the crop lands.

\section{9) Hardness, Calcium carbonate $\left(\mathrm{CaCO}_{3}\right)$}

The total hardness of water is comprised of the calcium and magnesium concentrations expressed as $\mathrm{mg} / \mathrm{l} \mathrm{CaCO}_{3}$. The increased concentration of these metals in rocks causes very considerable hardness levels in surface and ground waters [29]. From Table 1, there was relatively high within site variability of calcium carbonate $\left(\mathrm{CaCO}_{3}\right)$ concentrations in the upstream (CV; 40.78\% - 64.15\%) with slightly high mean $\mathrm{CaCO}_{3}$ values ranging from $23.17 \mathrm{mg} / \mathrm{l}$ (Kasharara) to $67.33 \mathrm{mg} / \mathrm{l}$ (Nyakafumura). The variation of $\mathrm{CaCO}_{3}$ within site was still higher in the midstream (CV; $28.84 \%$ - 69.05\%) with yet higher mean values fluctuating between $50.33 \mathrm{mg} / \mathrm{l}$ (Bugongi) and $91.83 \mathrm{mg} / \mathrm{l}$ (Nyakambu). Further still, the 
within site variability of $\mathrm{CaCO}_{3}$ in downstream was much higher $(\mathrm{CV} ; 31.34 \%$ 98.03\%). The downstream recorded much higher mean $\mathrm{CaCO}_{3}$ values ranging from $50.50 \mathrm{mg} / \mathrm{l}$ (Nyamabare) to $588.67 \mathrm{mg} / \mathrm{l}$ (Bus park stream).

The waters of the streams in the study sites ranged from soft to moderately soft (upstream), moderately soft (midstream) and moderately soft to excessively hard (downstream). The classification of waters by hardness according to EPA [29] is as follows: Soft (up to $50 \mathrm{mg} / 1 \mathrm{CaCO}_{3}$ ), Moderately Soft (51 - $100 \mathrm{mg} / \mathrm{l}$ $\mathrm{CaCO}_{3}$ ), Slightly Hard (101 - $150 \mathrm{mg} / 1 \mathrm{CaCO}_{3}$ ), Moderately Hard (151 - $250 \mathrm{mg} / \mathrm{l}$ $\mathrm{CaCO}_{3}$ ), Hard (251 - $350 \mathrm{mg} / \mathrm{CaCO}_{3}$ ) and Excessively Hard (over $350 \mathrm{mg} / \mathrm{l}$ $\left.\mathrm{CaCO}_{3}\right)$.

In general, $\mathrm{CaCO}_{3}$ amounts differed significantly across the sampling sites $(\mathrm{p}<$ 0.05). Bus park stream had the highest value of $\mathrm{CaCO}_{3}$ while Kasharara stream had the lowest value. The mean $\mathrm{CaCO}_{3}$ amounts also significantly increased from the upstream to midstream and downstream ( $\mathrm{p}<0.05)$ with the June-August sampling period having slightly higher $\mathrm{CaCO}_{3}$ content than the March-May period though the variation was statistically insignificant $(t=1.525, \mathrm{p}=0.131)$.

The amount of calcium increased from upstream, midstream to downstream simply due to strong loading as a result of influence of waste water on the river hydrochemistry. According to Ojok et al. [12], there is an influx of considerable amount of inorganic pollutants from Mbarara Municipality into river Rwizi. The slightly higher amount of $\mathrm{CaCO}_{3}$ in the streams during June-August sampling period (mainly dry season) compared to the March-April period (short rain season) could also be due to the concentration of the metal at high temperatures as further supported by the significant positive correlation of $\mathrm{CaCO}_{3}$ with temperature (Table 2).

\section{0) Magnesium (Mg)}

Magnesium is a mineral element with great diversity of uses within the animal bodies and essential for body functions in fish [44]. Magnesium is a major dietary requirement for humans (0.3 - $0.5 \mathrm{~g} /$ day) and is the second major constituent of hardness constituting 15 - 20 per cent of the total hardness expressed as $\mathrm{CaCO}_{3}[29]$.

The within site variability of magnesium concentrations was a bit high in the upstream $(\mathrm{CV} ; 38.26 \%$ - 70.60\%) with relatively low mean $\mathrm{Mg}$ values fluctuating between $4.41 \mathrm{mg} / \mathrm{l}$ (Kasharara) to $15.29 \mathrm{mg} / \mathrm{l}$ (Nyakafumura) (Table 1). Similarly the variation of $\mathrm{Mg}$ was slightly high at the midstream (CV; 17.94\% - 65.90\%) with relatively higher mean $\mathrm{Mg}$ values ranging from 9.41 (Bugongi) to 17.12 (Nyakambu). The within site variability of $\mathrm{Mg}$ was much higher downstream $(\mathrm{CV} ; 34.92 \%$ - 102.21\%) and the mean $\mathrm{Mg}$ values ranged from $7.90 \mathrm{mg} / \mathrm{l}$ to $121.89 \mathrm{mg} / \mathrm{l}$ at Nyamabare and Bus park stream respectively. Bus park stream was the only stream with mean Mg values higher than the NEMA permissible value $(100 \mathrm{mg} / \mathrm{l})$ for wastewater while the rest of the streams had mean $\mathrm{Mg}$ values below the guideline value.

On overall, there was significant variation of mean $\mathrm{Mg}$ values across the sam- 
pling sites $(\mathrm{p}<0.05)$. Bus park stream recorded the highest $\mathrm{Mg}$ concentrations and Kasharara stream had the least value. The mean magnesium concentrations significantly increased from the upstream to midstream and downstream sections of river Rwizi $(\mathrm{p}<0.05)$. The June-August sampling period (mainly dry season) recorded an insignificantly higher magnesium content than the March-April (short rain) sampling period $(t=1.476, \mathrm{p}=0.144)$. Similar seasonal variation of $\mathrm{Mg}$ was obtained by [44]. The significant $(\mathrm{p}<0.05)$ positive correlation of $\mathrm{Mg}$ with temperature (Table 2) supports the fact that $\mathrm{Mg}$ is concentrated at high temperatures.

\section{1) Iron (Fe)}

Iron occurs naturally in soil, rivers, lakes, sediments and ground water and is the second most abundant metal in the earth's crust accounting for about $5 \%$. Much as iron is an essential element for living organisms, it is also a heavy metal which is not biologically degradable unlike most organic pollutants and poses health risk at high concentrations [45] [46].

The within site variability of iron (Fe) concentration was quite high (CV; $37.39 \%-62.51 \%$ ) upstream with mean Fe values fluctuating from 0.12 to 1.22 $\mathrm{mg} / \mathrm{l}$ in Karungu and Kibimba respectively (Table 1). On the other hand, the variation of $\mathrm{Fe}$ was a bit low at the midstream $(\mathrm{CV} ; 31.83 \%-39.89 \%)$ with relatively higher mean $\mathrm{Fe}$ concentrations ranging from 0.26 (Nyakambu) to 1.67 (Bugongi). The within site variability of $\mathrm{Fe}$ was much higher downstream (CV; $2.70 \%-106.10 \%$ ) with also higher mean values ranging from 0.19 to 3.44 at $\mathrm{Ka}$ kyeka upper and Rwentondo respectively. The mean Fe contents in all the studied streams were lower than the NEMA permissible level in wastewater (10 mg/l). The mean Fe content in Kasharara, Karungu, Nyakafumura (upstream) and Kakyeka upper stream (midstream) were lower than the EPA guideline range $(0.2-2.0 \mathrm{mg} / \mathrm{l})$ while Fe levels in Kafunjo (midstream), Katete bridge, Rwentondo (downstream) were higher than the EPA values. The Fe concentrations in the rest of the streams in the upstream, midstream and downstream were within the EPA range.

On overall, iron contents were significantly different in the various streams/ channels ( $\mathrm{p}<0.05)$ with Rwentondo having the highest iron levels while Karungu stream had the lowest value. On overall, the amounts of iron were significantly highest $(p<0.05)$ downstream followed by midstream and lastly the upstream sections of river Rwizi. The June-August sampling period still recorded slightly higher concentrations of iron than the March-May period but the variation was insignificant $(\mathrm{p}>0.05)$.

Iron was significantly highest downstream due to iron release from industrial and municipal waste discharge since the downstream comprises of Mbarara municipality which is an urbanized and industrialized area. Some of the activities carried out in the downstream that release iron into the environment include; staining from laundries, plumbing and welding, milk and food industries and water treatment plants where cast iron, steel, and galvanized iron pipes that are 
used in water distribution [46]. The slightly higher concentration of Fe during the June-August period may also be attributed to concentration of $\mathrm{Fe}$ at slightly higher temperature during the relatively dry season.

\section{2) Phosphates ( $\mathrm{PO}_{4}^{3-}$ )}

Phosphate is a very essential nutrient for the growth of plants and animals. But high concentrations of phosphates in water environments causes eutrophication leading to excessive growth of algae and aquatic plants, which chokes up the waterways and use up large amounts of oxygen. This process in turn causes the death of aquatic life because of the lowering of dissolved oxygen levels [47]. The within site variation of phosphate concentrations was high $(\mathrm{CV} ; 36.86 \%$ $103.94 \%)$ at the upstream with relatively low mean values ranging from 0.24 $\mathrm{mg} / \mathrm{l}$ (Kibimba) to $1.16 \mathrm{mg} / \mathrm{l}$ (Karungu) (Table 1 ). The mean phosphate values in Kasharara and Kibimba streams in the upstream were lower than the EPA guideline range $(0.5-0.7 \mathrm{mg} / \mathrm{l})$ while mean $\mathrm{PO}_{4}^{3-}$ concentration in Karungu was higher than EPA range. The mean $\mathrm{PO}_{4}^{3-}$ level only in Nyakafumura stream in the upstream was within the EPA standard range.

The within site variation of phosphates was relatively low at the midstream (CV; 20.65\% - 28.48\%) with lower mean values ranging from $0.30 \mathrm{mg} / \mathrm{l}$ (Bugongi) to $0.68 \mathrm{mg} / \mathrm{l}$ (Nyakambu). The mean phosphate concentration in Bugongi stream was below the EPA range while mean $\mathrm{PO}_{4}^{3-}$ amount in Nyakambu stream was within the EPA range.

The within site variability of Phosphates was a bit high downstream (CV; $28.31 \%-83.07 \%$ ) with much higher mean values alternating between $0.89 \mathrm{mg} / \mathrm{l}$ and $12.85 \mathrm{mg} / \mathrm{l}$ at Kafunjo and Kikutu stream respectively. The mean phosphate levels in all the streams in the downstream were higher than the EPA standard range $(0.5-0.7 \mathrm{mg} / \mathrm{l})$.

Mean phosphate levels in only Kikutu and Katete bridge streams in the downstream were higher than the NEMA permissible limit for wastewater $(10 \mathrm{mg} / \mathrm{l})$ while the rest of the streams in the downstream, midstream and upstream had mean $\mathrm{PO}_{4}^{3-}$ amounts below the NEMA standard.

On overall, there was significant variation of mean phosphate concentrations across the sampling sites $(\mathrm{p}<0.05)$ with Kikutu stream having the highest amounts of phosphates whereas the least amount was in Kibimba stream. Phosphate amounts were significantly $(\mathrm{p}<0.05)$ highest in the downstream followed by the upstream and lastly the midstream. The June-August period had slightly higher phosphates than the March-May period with an insignificant variation $(\mathrm{t}$ $=1.571, \mathrm{p}=0.120)$. The high phosphates in the downstream particularly in Kikutu and Katete bridge streams originate from use of detergents for bathing, washing of clothes and automobiles in these streams as the mentioned activities are commonly practiced by the people in these streams. In addition, poorly managed sewage in Mbarara municipality could have also contributed to the elevated phosphate levels. According to EPA [29], phosphorus is also a major constituent of detergents especially those for domestic use. Phosphate is also one of 
the most important nutrients in waters receiving sewage discharges [48]. Hence surface run-off and sewage discharges are some of the key contributors of phosphorus to surface waters [29].

\section{3) Nitrates $\left(\mathrm{NO}_{3}\right)$}

Nitrate is a very useful nutrient for the growth of plants and animals and high levels of the nutrient in water bodies also causes eutrophication with disastrous effect of reduction of oxygen levels in water bodies which affects aquatic life [43] [47] [49]. Nitrate concentrations were only recorded at Karungu in the upstream and exhibited very high within site variability $(\mathrm{CV}=109.54 \%)$ with a mean value of $5.0 \mathrm{mg} / \mathrm{l}$ (Table 1). Other sites in the upstream did not register any nitrate amounts. No nitrate content was also recorded in the midstream at the selected sampling sites. In the downstream sites where nitrate levels were recorded, there was very high within sample variability (CV; 73.94\% - 154.92\%) with high mean nitrate concentrations ranging from $3.33 \mathrm{mg} / \mathrm{l}$ (Kikutu stream) and $10.83 \mathrm{mg} / \mathrm{l}$ (Kakyeka GBK). All the sampling sites upstream and downstream which registered some nitrate concentrations had nitrate levels lower than the EPA standard value of $50 \mathrm{mg} / \mathrm{l}$.

There was also a significant variation of nitrate concentrations across the sampling sites $(\mathrm{p}<0.05)$ with Kakyeka GBK having the highest amounts of nitrates whereas Kikutu stream recorded the lowest nitrate concentration. The downstream sites recorded insignificantly $(p>0.05)$ higher overall mean nitrate concentration than the upstream while the midstream had no nitrate content (Figure 3). The March-May sampling period recorded insignificantly higher nitrate concentrations than the June-August sampling period $(\mathrm{t}=1.058, \mathrm{p}=$ 0.293).

Karungu in the upstream exhibited some nitrate levels because the stream is very close to a primary school with all the sewage generated from the school ending up into the stream and subsequently into the river. Also surrounding the sampling points were banana plantations, tree plantations and cattle farms with the runoffs or seepage from fertilized agricultural lands entering also ending up in the river. The high nitrate levels in Kakyeka GBK stream in the downstream may be attributed to the organic matter rich effluents from the GBK milk factory while nitrate concentrations recorded in Kikutu stream (downstream) is mainly attributed to municipal and industrial wastewater, refuse dumps, septic tanks, sewage disposal and urban drainage in Mbarara Municipality [35]. According to EPA [29], most nitrates in natural waters come from organic (waste discharges) and inorganic (artificial fertilisers) sources with little from mineral origin.

\section{4) Ammonium ions $\left(\mathrm{NH}_{4}^{+}\right)$}

Ammonium is the preferred nitrogen-containing nutrient for plant growth and aquatic organisms. However ammonia is also one of the most important pollutants because it is relatively common and can be toxic, causing lower reproduction and growth, or death to fish and other aquatic life [50] [51]. The forms of the ammonia i.e. "free" (as $\mathrm{NH}_{3}$ ) or "saline" (as $\mathrm{NH}_{4}^{+}$) in slightly acid 
waters is dependent on the $\mathrm{pH}$ and these forms are indistinguishable from one another during analysis and the natural interconversion from one form to another (i.e. $\mathrm{NH}_{3}+\mathrm{H}_{2} \mathrm{O} \rightarrow \mathrm{NH}_{3} \cdot \mathrm{H}_{2} \mathrm{O} \rightarrow \mathrm{NH}_{4}^{+}+\mathrm{OH}^{-}$) is easy [29]. Ammonia indicates the possibility of sewage pollution and the consequent presence of pathogenic micro-organisms.

The ammonium $\left(\mathrm{NH}_{4}^{+}\right)$concentrations within the sampling sites in the upstream where ammonium was recorded varied greatly (CV; 77.46\% - 244.95\%) with the lowest mean value $(1.67 \mathrm{mg} / \mathrm{l})$ recorded in Karungu while the highest ( $6.67 \mathrm{mg} / \mathrm{l}$ ) was in Kibimba (Table 1). The mean ammonium concentrations in Kibimba and Nyakafumura were higher than the EPA standard range (0.2 - 4 $\mathrm{mg} / \mathrm{l}$ ) while mean $\mathrm{NH}_{4}^{+}$level in Karungu stream was within the EPA range. No ammonium ions were recorded at Kasharara in the upstream.

The within site variation of ammonium was also high (109.54\%) in Bugongi stream at the midstream with a slightly higher mean value of $5.00 \mathrm{mg} / \mathrm{l}$. The mean ammonium concentration in Bugongi was also higher than the EPA range. No ammonium was recorded at Nyakambu in the midstream.

The within sample variability of ammonium in sites at the downstream where ammonium was recorded was very high (CV; 44.54\% - 244.95\%) with very high mean values ranging from $1.67 \mathrm{mg} / \mathrm{l}$ (Kafunjo) to $46.67 \mathrm{mg} / \mathrm{l}$ (Kakyeka upper). The mean ammonium concentrations in Kakyeka GBK, Kakyeka upper, Bus park stream, Kikutu stream and Rwentondo stream were higher than the EPA standard range. No ammonium was recorded at Katete bridge and Nyamabare in the downstream.

According to EPA [29], ammonia is present in natural waters in very small amounts due to microbiological activity which causes the reduction of nitrogencontaining compounds. When levels exceed $0.1 \mathrm{mg} / \mathrm{l} \mathrm{N}$, sewage or industrial contamination may be indicated. Hence the recorded high $\mathrm{NH}_{4}^{+}$concentrations in the streams point to sewage disposal and industrial contamination of those streams.

On overall, the ammonium concentrations significantly varied across the sampling sites of the stream $(\mathrm{p}<0.05)$. Kakyeka upper had the highest ammonium levels while Karungu and Kafunjo had the least mean levels of ammonium especially at sites where ammonium was recorded.

Ammonium content was significantly highest in the downstream followed by the upstream and lastly the midstream $(p<0.05)$. There was slightly more ammonium concentration recorded during the March-May sampling period than the June-August period but the difference was not significant $(\mathrm{t}=0.056, \mathrm{p}=$ 0.955). The source of ammonium downstream was residential and industrial processes as well as sewage treatment plants in Mbarara municipality. This is in agreement with [29] [36] [50]. The slightly higher ammonium concentration in the March-May period is associated with surface runoff of sewage during the short rains.

\section{5) Chloride ( $\mathrm{Cl})$}

Chloride occurs in all-natural waters with widely varying concentrations 
reaching a maximum of up to $35,000 \mathrm{mg} / \mathrm{l}$ in sea water [29]. The Sources of chloride in fresh waters include soil and rock formations, sea spray as well as waste discharges. In the present study, chloride was only recorded in the downstream in Bus park and Kikutu streams (Table 1). Chloride exhibited high variability within samples (CV; 77.46\% - 109.54\%) in these streams with very high mean values ranging from $250 \mathrm{mg} / \mathrm{l}$ (Kikutu stream) and $333.33 \mathrm{mg} / \mathrm{l}$ (Bus park stream). The mean chloride values recorded at the Bus park stream was higher than the EPA guideline value $(250 \mathrm{mg} / \mathrm{l})$ while mean chloride level in Kikutu stream was within the EPA standard value. On the other hand, mean chloride concentrations in both streams were below the NEMA standard for wastewater (500 mg/l).

Chloride concentrations significantly varied in the two sampling sites downstream ( $\mathrm{p}<0.05)$. The March-May sampling recorded registered an insignificantly higher $\mathrm{Cl}$ than the June-August sampling period $(\mathrm{t}=0.424, \mathrm{p}=0.673)$. The high levels of chloride in the channels found downstream were also associated with industrial and municipal wastes. [31] also found high levels of chloride downstream of River Betwa, Vidisha District and attributed it to anthropogenic activities like septic tank effluents, use of bleaching agents by launderers and washing of clothes. According to EPA [29], sewage contains large amounts of chloride like some industrial effluents. As such, sewage is a rich source of chloride and high levels may indicate pollution of water by a sewage effluent. Furthermore, rivers and other fresh waters usually have natural chloride levels between 15 - $35 \mathrm{mg} / \mathrm{l}$ [29]. Hence the elevated concentrations of chloride in Kikutu $(250 \mathrm{mg} / \mathrm{l})$ and Bus park $(333.33 \mathrm{mg} / \mathrm{l})$ streams may be attributed to sewage discharge into these streams from Mbarara Municipality. In addition, the slightly high $\mathrm{NH}_{4}^{+}$in these streams confirms sewage discharge into the streams. According to EPA [29], an increase in chloride levels of about $5 \mathrm{mg} / \mathrm{l}$ in a site raises suspicions of sewage discharge, especially if the free ammonia levels are also elevated.

\section{Conclusion}

A range of physico-chemical parameters in the streams draining into river Rwizi have been greatly compromised by the various anthropogenic activities carried out around these water sources and a gradient of increasing contamination has been observed from the upstream, midstream and the downstream. Hence the streams in the downstream recorded the highest levels of the physico-chemical parameters (temperature, Total suspended solids, alkalinity, Magnesium, Calcium Carbonate, Chlorine, turbidity, Electric Conductivity, Dissolved Oxygen, Phosphates, $\mathrm{pH}$, Ammonium, Iron, Nitrates) followed by the midstream and lastly the upstream. The levels of most of the parameters (e.g. temperature, Total suspended solids, alkalinity, Magnesium, Calcium Carbonate, Chlorine, Dissolved Oxygen, Phosphates, $\mathrm{pH}$, Ammonium, Iron) in the downstream were higher than the EPA and NEMA standards while the levels of the studied para- 
meters in the streams and channels at the upstream were below or within the standard values except DO. However, the most impacted stream was bus park stream in the downstream and the least impacted was Kasharara in the upstream. Calcium carbonate hardness of the waters of the streams ranged from soft to moderately soft (upstream), moderately soft (midstream) and moderately soft to excessively hard (downstream). March to May and June to August sampling periods recorded fluctuating high and low values of the physico-chemical parameters without a clear seasonal pattern signifying the erratic weather patterns (i.e. less distinct rain and dry seasons) during the study period possibly associated with climatic changes.

\section{Acknowledgements}

The authors would like to extend their acknowledgement to African Development Bank Hest, Mbarara University of Science and Technology, for providing the financial support.

Microbiology Department Faculty of Medicine, National water and Sewerage co-operation, Biology Department faculty of science for their collaboration in carrying out the analyses in their laboratories.

Mr. Edson Agaba and Mr. Nickson Araka my research assistants. Mr. James Mwesigye, Mr. Rapheal Wangalwa, Mr. Julius Tumusiime, for their time whenever approached for assistance.

\section{Conflicts of Interest}

The authors declare no conflicts of interest regarding the publication of this paper.

\section{References}

[1] Hutton, G. and Chase, C. (2016). The Knowledge Base for Achieving the Sustainable Development Goal Targets on Water Supply, Sanitation and Hygiene. International Journal of Environmental Research and Public Health, 13, 1-35.

[2] WHO/UNICEF Joint Water Supply, \& Sanitation Monitoring Programme (2014) Progress on Drinking Water and Sanitation: 2014 Update. World Health Organization.

[3] Adejuwon, J.O. and Mbuk, C.J. (2011) Biological and Physiochemical Properties of Shallow Wells in Ikorodu Town, Lagos Nigeria. Journal of Geology and Mining Research, 3, 161-168.

[4] Mustapha, M.K. and Omotoso, J.S. (2005) An Assessment of the Physico-Chemical Properties of Moro Lake. African Journal of Applied Zoology and Environmental Biology, 7, 73-77.

[5] Sangpal, R.R., Kulkarni, U.D. and Nandurkar, Y.M. (2011) An Assessment of the Physico-Chemical Properties to Study the Pollution Potential of Ujjani Reservoir, Solapur District, India. ARPN Journal of Agriculture and Biological Science, 6, 34-38.

[6] Murugan, K., Prabhakaran, P., Al-Sohaibani, S. and Sekar, K. (2012) Identification of Source of Faecal Pollution of Tirumanimuttar River, Tamilnadu, India Using 
Microbial Source Tracking. Environmental Monitoring and Assessment, 184, 60016012 .

[7] Deepak, S. and Singh, N.U. (2014) The Relationship between Physico-Chemical Characteristics and Fish Production of Mod Sagar Reservoir of Jhabua District, MP, India. Research Journal of Recent Sciences, 3, 82-86.

[8] Thirumala, S., Kiran, B.R. and Kantaraj, G.S. (2011) Fish Diversity in Relation to Physico-Chemical Characteristics of Bhadra Reservoir of Karnataka, India. Advances in Applied Science Research, 2, 34-47.

[9] Mbalassa, M., Bagalwa, J.J.M., Nshombo, M. and Kateyo, M.E. (2014) Assessment of Physicochemical Parameters in Relation with Fish Ecology in Ishasha River and Lake Edward, Albertine Rift Valley, East Africa. International Journal of Current Microbiology and Applied Sciences, 3, 230-244.

[10] Songa, P., Rumohr, J. and Musota, R. (2015) A Shared Water Risk Assessment for a Vulnerable River Basin: River Rwizi in Uganda. WIT Transactions on Ecology and the Environment, 197, 213-224.

[11] Abila, R., Mutemi, M., Mutuku, E., Mutati, K., Mutinda, M. and Musyoka, C.M. (2012) Physico-Chemical and Bacteriological Quality Assessment of Shallow Wells in Kitui Town, Kenya.

[12] Ojok, W., Wasswa, J. and Ntambi, E. (2017) Assessment of Seasonal Variation in Water Quality in River Rwizi Using Multivariate Statistical Techniques, Mbarara Municipality, Uganda. Journal of Water Resource and Protection, 9, 83.

[13] Egor, M., Mbabazi, J. and Ntale, M. (2012) Heavy Metal and Nutrient Loading of River Rwizi by Effluents from Mbarara Municipality, Western Uganda. Doctoral Dissertation, Makerere University.

[14] Mugonola, B., Mathijs, E., Poesen, J., Deckers, J., Wanyama, J. and Isabirye, M. (2015) Conserving Soils: Soil and Water Conservation Technologies in the Upper Rwizi Microcatchment of Southwestern Uganda. International Water Management Institute (IWMI); CGIAR Research Program on Water, Land and Ecosystems (WLE); Global Water Initiative East Africa (GWI EA).

[15] Songa, P., Rumohr, J. and Musota, R. (2015) Policy and Institutional Framework Considerations in the Implementation of Catchment-Based Water Resources Management in Uganda: Highlights from the River Rwizi Catchment. WIT Transactions on Ecology and the Environment, 196, 15-26.

[16] Mbarara District Local Government (2013) River Rwizi.

[17] Mukwaya, C. and Mugabe, R. (2012) Cooperation in Management of Water Resources in the Ruizi Catchment, Southwestern Uganda.

[18] Zhu, K.H., Xu, X.R., Sun, D.F., Tang, J.L. and Zhang, Y.K. (2014) Effects of Drinking Water Acidification by Organic Acidifier on Growth Performance, Digestive Enzyme Activity and Caecal Bacteria in Growing Rabbits. Animal Feed Science and Technology, 190, 87-94. https://doi.org/10.1016/j.anifeedsci.2014.01.014

[19] Venkatesharaju, K., Ravikumar, P., Somashekar, R.K. and Prakash, K.L. (2010) Physico-Chemical and Bacteriological Investigation on the River Cauvery of Kollegal Stretch in Karnataka. Kathmandu University Journal of Science, Engineering and Technology, 6, 50-59. https://doi.org/10.3126/kuset.v6i1.3310

[20] Bahiru, E.A., Woldai, T. and De Smeth, D. (2011) Inter-Relationship between Lithology and Structure and Its Control on Gold Mineralization in Buhweju Area, SW of Uganda. University of Twente Faculty of Geo-Information and Earth Observation (ITC).

[21] Semalulu, O. and Kaizzi, C.K. (2012) Overview of the Status of Soil Resource in 
Uganda, and the Needs and Priorities for Its Sustainable Management. https://www.slideshare.net/FAOoftheUN/overview-of-the-status-of-soil-resource-in -uganda-and-the-needs-and-priorities-for-its-sustainable-management-onesmus-se malulu-kayuki-c-kaizzi-narokawanda

[22] Mackereth, F.J.H., Heron, J. and Talling, J.F. (1978) Water Analyses. Freshwater Biological Association, London, 120.

[23] Akintoye, O.A., Obi, C.N., Etim, O.A., Olorundami, T., Ukata, S.U. and Harrison, U. (2014) Seasonal Variation in the Physico-Chemical Characteristics of Surface Water in Etche River, Niger Delta Area of Nigeria. Journal of Environmental Science, Toxicology and Food Technology, 8, 1-7. https://doi.org/10.9790/2402-08710107

[24] Fagan, H.G., Linnane, S., McGuigan, G.K. and Rugumayo, I.A. (2015) Water Is Life, Progress to Secure Safe Water Provision in Rural Uganda Rugby. Practical Action Publishing. https://doi.org/10.3362/9781780448893

[25] Hongve, D. and Åkesson, G. (1996) Spectrophotometric Determination of Water Colour in Hazen Units. Water Research, 30, 2771-2775. https://doi.org/10.1016/S0043-1354(96)00163-7

[26] Hach Company (1959) Suspended Solids. Photometric Method. Edition 6, Method 8006. https://camblab.info/wp/wp-content/uploads/2011/09/suspendedsolidsmethod.pdf

[27] Kitonsa, W. and Schwartz, K. (2012) Commercialisation and Centralisation in the Ugandan and Zambian Water Sector. International Journal of Water, 6, 176-194. https://doi.org/10.1504/IJW.2012.049495

[28] Andreolli, M., Giovannini, M., Fatone, F., Kyamunyogonya, M. and Yatuha, J. (2015) A Basic Bottom-Up Approach for Small Systems of Safe-Water Supply: A Decentralized Case Study in Uganda. Journal of Water Supply: Research and Technology-AQUA, 64, 105-116. https://doi.org/10.2166/aqua.2014.119

[29] EPA (2001) Parameters of Water Quality: Interpretation and Standards. Wexford. https://www.epa.ie/pubs/advice/water/quality/Water_Quality.pdf

[30] NEMA (1999) National Environment (Standards for Discharge of Effluent or Waste Water into Water or on Land) Regulations. National Environment Management Authority (NEMA), Government of the Republic of Uganda, Kampala. http://nema.go.ug/sites/all/themes/nema/docs/effluent_discharge_regulations.pdf

[31] Patel, A. and Datar, M. (2014) Seasonal Variations of Physico-Chemical Characteristics of River Betwa in Vidisha District. International Journal of Environmental Science and Technology, 3, 2205-2214.

[32] Wagner, T., Midway, S.R., Whittier, J.B., DeWeber, J.T. and Paukert, C.P. (2017) Annual Changes in Seasonal River Water Temperatures in the Eastern and Western United States. Water, 9, 90. https://doi.org/10.3390/w9020090

[33] Cooper, M. (2010) Advanced Bash Scripting Guide 5.3. Volume 1.

[34] Muhangane, L., Nkurunungi, J.B., Yatuha, J. and Andama, M. (2017) Suitability of Drinking Water Sources from Nyaruzinga Wetland for Domestic Use in Bushenyi Municipality, Uganda. Journal of Water Resource and Protection, 9, 1587. https://doi.org/10.4236/jwarp.2017.913100

[35] Bashemereirwe, C. (2009) Socio-Economic Activities Impacting on Rwizi Riverine Wetlands, South Western Uganda. https://www.must.ac.ug/sites/default/files/Socio....pdf

[36] Iqbal, F., Ali, M., Salam, A., Khan, B.A., Ahmad, S., Qamar, M. and Umer, K. (2004) Seasonal Variations of Physico-Chemical Characteristics of River Soan Water at 
Dhoak Pathan Bridge (Chakwal), Pakistan. International Journal of Agriculture and Biology, 6, 89-92.

[37] Lukubye, B. and Andama, M. (2017) Physico-Chemical Quality of Selected Drinking Water Sources in Mbarara Municipality, Uganda. Journal of Water Resource and Protection, 9, 707-722. https://doi.org/10.4236/jwarp.2017.97047

[38] Meng, Z., Xu, X., Lin, W., Ge, B., Xie, Y., Song, B. and Cheng, H. (2018) Role of Ambient Ammonia in Particulate Ammonium Formation at a Rural Site in the North China Plain. Atmospheric Chemistry and Physics, 18, 167-184. https://doi.org/10.5194/acp-18-167-2018

[39] Mahazar, A., Shuhaimi-Othman, M., Kutty, A.A. and Desa, M.N. (2013) Monitoring Urban River Water Quality Using Macroinvertebrate and Physico-Chemical Parameters Case Study of Penchala River, Malaysia. Journal of Biosocial Science, 13, 474-482. https://doi.org/10.3923/jbs.2013.474.482

[40] Cobbina, S.J., Michael, K., Salifu, L. and Duwiejua, A.B. (2013) Rainwater Quality Assessment in the Tamale Municipality. International Journal of Scientific \& Technology Research, 2, 1-10.

[41] Rahmanian, N., Ali, S.H.B., Homayoonfard, M., Ali, N.J., Rehan, M., Sadef, Y. and Nizami, A.S. (2015) Analysis of Physiochemical Parameters to Evaluate the Drinking Water Quality in the State of Perak, Malaysia. Journal of Chemistry, 2015, Article ID: 716125. https://doi.org/10.1155/2015/716125

[42] Sharma, R., Kumar, A. and Vyas, V. (2013) Diversity of Macrozoobenthos in Morand River-A Tributary of Ganjal River in Narmada Basin. International Journal of Advanced Fisheries and Aquatic Science, 1, 57-65.

[43] Gorchev, H.G. and Ozolins, G. (2011) WHO Guidelines for Drinking-Water Quality. WHO Chronicle, 38, 104-108.

[44] Ebigwai, J.K., Imedimfon, I.E., Bright, H.A., Olowu, C. and Ekanem, F.A. (2014) Physico Chemical Parameters and Phytoplankton Assemblages along Spatial and Temporal Gradients in Great Kwa River, Calabar, Nigeria. International Journal of Biological Chemistry, 8, 1-20. https://doi.org/10.3923/ijbc.2014.1.20

[45] Yasin, M., Ketema, T. and Bacha, K. (2015) Physico-Chemical and Bacteriological Quality of Drinking Water of Different Sources, Jimma Zone, Southwest Ethiopia. BMC Research Notes, 8, 541. https://doi.org/10.1186/s13104-015-1376-5

[46] WHO (2003) Iron in Drinking-Water Background Document for Development of WHO Guidelines for Drinking-Water Quality. World Health Organization Guidelines, 2, 1-9.

[47] Kotoski, E.J. (1997) Information on Phosphorus Amounts \& Water Quality Environmental Impact. Spring Harbor Environmental Magnet Middle School, 1-4.

[48] Adeyemo, O.K., Adedokun, O.A., Yusuf, R.K. and Adeleye, E.A. (2008) Seasonal Changes in Physico-Chemical Parameters and Nutrient Load of River Sediments in Ibadan City, Nigeria. Global Nest Journal, 10, 326-336.

[49] Yamamura, S., Bartram, J., Csanady, M., Gorchev, H.G. and Redekopp, A. (2003) Drinking Water Guidelines and Standards. Arsenic, Water, and Health: The State of the Art.

[50] Hargreaves, J.A. and Tucker, C.S. (2004) Managing Ammonia in Fish Ponds (Vol. 4603). Southern Regional Aquaculture Center, Stoneville.

[51] WHO (1996) Chromium in Drinking-Water Background Document for Development of WHO Guidelines for Drinking-Water Quality. Health San Francisco, 2. http://www.nap.edu/catalog/9038/nitrate-and-nitrite-in-drinking-water http://www.nap.edu/catalog/9038.html 